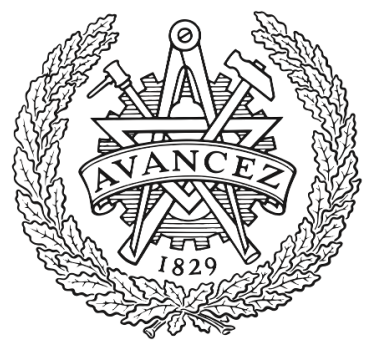

CHALMERS

UNIVERSITY OF TECHNOLOGY

\title{
Azulene functionalization by iron-mediated addition to a cyclohexadiene scaffold
}

Downloaded from: https://research.chalmers.se, 2023-04-26 08:06 UTC

Citation for the original published paper (version of record):

Dunås, P., Murfin, L., Nilsson, O. et al (2020). Azulene functionalization by iron-mediated addition to a cyclohexadiene scaffold. Journal of Organic Chemistry, 85(21): 13453-16465. http://dx.doi.org/10.1021/acs.joc.0c01412

N.B. When citing this work, cite the original published paper. 


\title{
Azulene Functionalization by Iron-Mediated Addition to a Cyclohexadiene Scaffold
}

\author{
Petter Dunås, Lloyd C. Murfin, Oscar J. Nilsson, Nicolas Jame, Simon E. Lewis, ${ }^{*}$ and Nina Kann*
}

Cite This: J. Org. Chem. 2020, 85, 13453-13465

Read Online

ABSTRACT: The functionalization of azulenes via reaction with cationic $\eta^{5}$-iron carbonyl diene complexes under mild reaction conditions is demonstrated. A range of azulenes, including derivatives of naturally occurring guaiazulene, were investigated in reactions with three electrophilic iron complexes of varying electronic properties, affording the desired coupling products in $43-98 \%$ yield. The products were examined with UVvis/fluorescence spectroscopy and showed interesting halochromic properties. Decomplexation and further derivatization of the products provide access to several different classes of 1-substituted azulenes, including a conjugated ketone and a fused tetracycle.

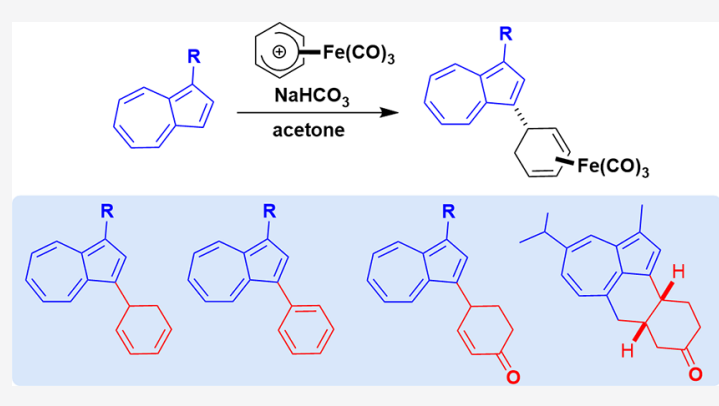

\section{INTRODUCTION}

Azulene is a bicyclic nonalternant aromatic hydrocarbon, isomeric with naphthalene. The $\pi$-electrons of azulene are polarized toward the five-membered ring, resulting in a relatively large inherent dipole moment and a deep blue color. ${ }^{1}$ Their unusual electronic properties make azulenes interesting as photocatalysts ${ }^{2}$ and colorimetric indicators ${ }^{3}$ and for optoelectronics such as solar cells, ${ }^{4}$ photoswitches, ${ }^{5}$ and organic electronics. ${ }^{6}$ Azulene derivatives have also found use in medicine in the form of antiulcer, ${ }^{7}$ antidiabetic, ${ }^{8}$ and anticancer ${ }^{9}$ agents. The ability to functionalize the azulene scaffold is thus of great interest.

Azulenes are potent nucleophiles for electrophilic aromatic substitution $\left(S_{\mathrm{E}} \mathrm{Ar}\right)$, with the 1- and 3-positions being the most reactive toward electrophiles. ${ }^{10}$ Reported methods for derivatizing azulenes include (a) the Michael addition, ${ }^{11}$ (b) Friedel-Crafts ${ }^{11 a, 12}$ and Vilsmeier-Haack reactions, ${ }^{11 a, 13}$ (c) azulene addition to heteroaromatic triflates, ${ }^{14}$ and (d) the formation of diazo compounds (Scheme 1). ${ }^{15}$ Azulenes are also susceptible to (e) electrophilic halogenations. ${ }^{10 e, 16}$ In addition, cross-coupling reactions have been reported. ${ }^{17}$ While these latter reactions are attractive for coupling the azulene to $\mathrm{sp}^{2}$ - and sp-carbons, they generally rely on the use of precious metal catalysts and require prefunctionalization of the azulene skeleton.

Another class of electrophile that could potentially react with nucleophilic azulenes are cationic $\eta^{5}$-iron carbonyl dienyl complexes (Scheme 2). Such complexes are capable of reacting with a wide range of nucleophiles to form new carbon-carbon or carbon-heteroatom bonds. ${ }^{18}$ Nucleophilic addition proceeds in a highly selective manner at the opposite face to the iron carbonyl moiety and at one of the ends of the conjugated system. ${ }^{18 \mathrm{~b}, 19}$ Substituents on the cation can act to direct the nucleophilic addition to either termini of the dienyl system;
Scheme 1. Electrophilic Aromatic Substitution Reactions for Functionalizing Azulenes

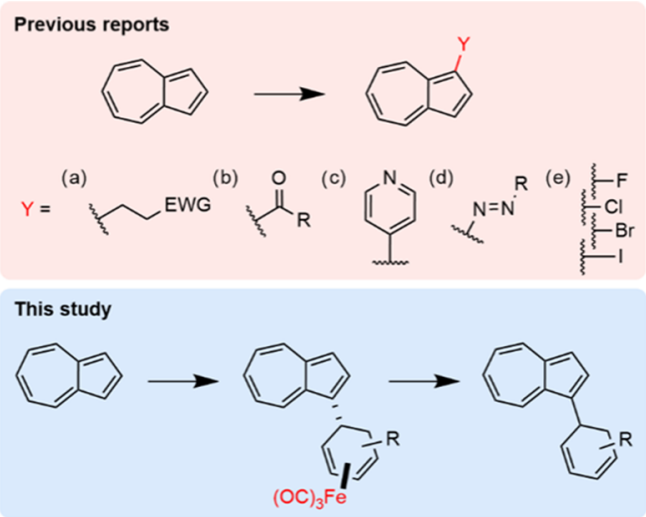

Scheme 2. Methods for the Formation of Cationic Iron Carbonyl Dienyl Complexes

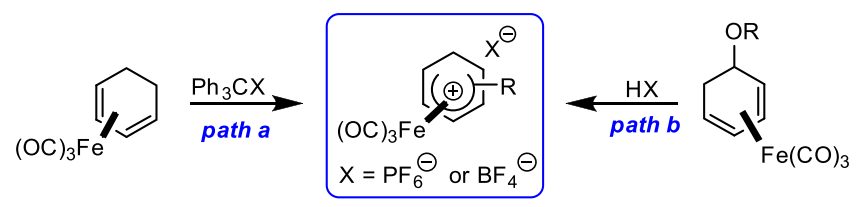

Received: June 15, 2020

Published: October 21, 2020 
electron-withdrawing groups will generally favor addition in the meta position, while electron-donating groups will often favor the para or ipso addition. ${ }^{20}$ The cationic complexes can be formed via hydride abstraction (Scheme 2, path a) or by acid treatment of a complex possessing a leaving group (Scheme 2, path b). Once formed, the complex can be isolated as a shelf-stable fine powder. ${ }^{42}$

Aromatic nucleophiles that can react with cationic iron carbonyl dienyl complexes include furan, ${ }^{21}$ indole, ${ }^{21,22}$ aniline, ${ }^{23}$ and oxygenated arenes. ${ }^{24}$ The scope was recently increased by us to include the selective $\mathrm{C}$ - or O-addition of phenolic nucleophiles. ${ }^{25}$ Although azulenes, with a nucleophilicity similar to that of indoles, ${ }^{10 \mathrm{~d}}$ can be expected to be efficient nucleophiles, no previous report of their use in this context has been reported. Herein, we present a convenient iron-mediated electrophilic $\mathrm{C}-\mathrm{H}$ functionalization of azulenes (Scheme 1). The products of this process are valuable in two contexts. First, they are stimuli-responsive substances with multimodal outputs (colorimetric, fluorescence, and infrared spectroscopic). Second, they are versatile substrates for further synthetic transformations such as cyclizations. The cyclohexadiene also constitutes a proaromatic substituent, which may be readily converted to a phenyl ring, giving a formal product of azulene electrophilic arylation, for which there is no direct $S_{E} A r$ equivalent.

\section{RESULTS AND DISCUSSION}

To investigate if azulenes could react with cationic iron carbonyl dienyl complexes, we selected guaiazulene $\mathbf{1}$ as the nucleophile, due to its low cost and availability from natural sources. As the electrophile, we selected iron complex 2 , which we have used in earlier studies. ${ }^{25}$ Optimization of the reaction conditions for this addition was then performed (Table 1).

Table 1. Optimization of the Addition of Guaiazulene (1) to Cationic Complex $2^{a}$

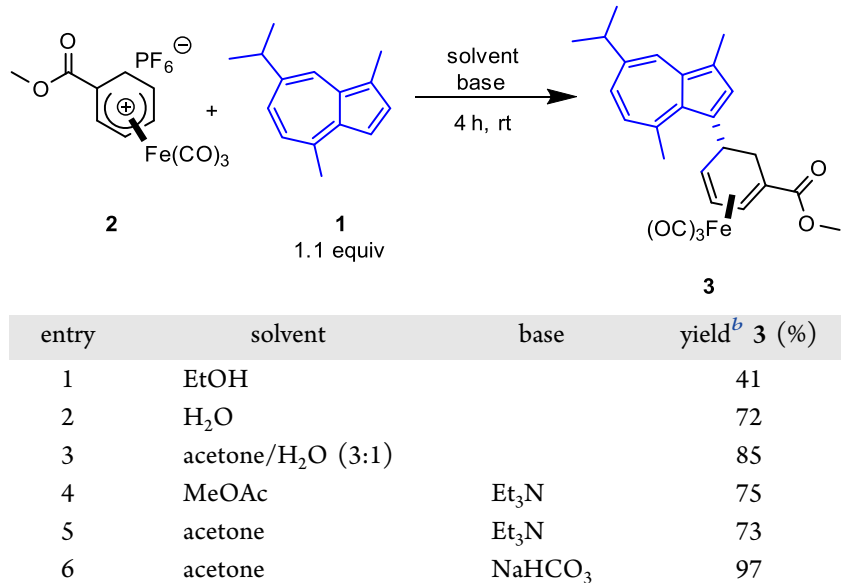

${ }^{a}$ Product 3 is racemic; relative stereochemistry is shown. ${ }^{b}$ Yields are determined by quantitative ${ }^{1} \mathrm{H}$ NMR using $p$-xylene as the internal standard.

In our previous studies involving phenolic nucleophiles, we performed the reaction in ethanol in the absence of base at an ambient temperature. ${ }^{25}$ Similar conditions here afforded the desired addition product 3 , albeit in a modest yield (Table 1 , entry 1). Using water as the solvent afforded a heterogeneous reaction mixture where both guaiazulene and iron complex 2 were insoluble. Nevertheless, the yield was increased to $72 \%$ (entry 2). To investigate if solubility issues might play a role in limiting the yield, the reaction was performed in a 3:1 mixture of acetone and water, resulting in an enhanced yield of $85 \%$ (entry 3). Adding an amine base such as triethylamine $\left(\mathrm{Et}_{3} \mathrm{~N}\right)$ was not beneficial, neither for methyl acetate as the solvent (entry 4) nor for acetone (entry 5). A near-quantitative yield could, however, be attained using acetone with sodium bicarbonate as the base (entry 6). This last protocol thus provides a set of green and benign reaction conditions for the addition reaction.

Azulene itself possesses two nucleophilic carbons, and a mixture of mono- and disubstituted products is thus to be expected. To see if azulene could be selectively functionalized to form either one of these products, the reaction was first performed using a slight excess of complex 2 relative to azulene. This afforded an equimolar mixture of the diastereomeric disubstituted azulenes 4 and $4^{\prime}$ in an $81 \%$ yield (Scheme 3 ). Using a large excess of azulene instead, a mixture of mono- and disubstituted products was formed, where the monosubstituted product $\mathbf{5}$ could be isolated in a yield of $48 \%$.

\section{Scheme 3. Mono- and Dialkylation of Azulene ${ }^{a, b}$}
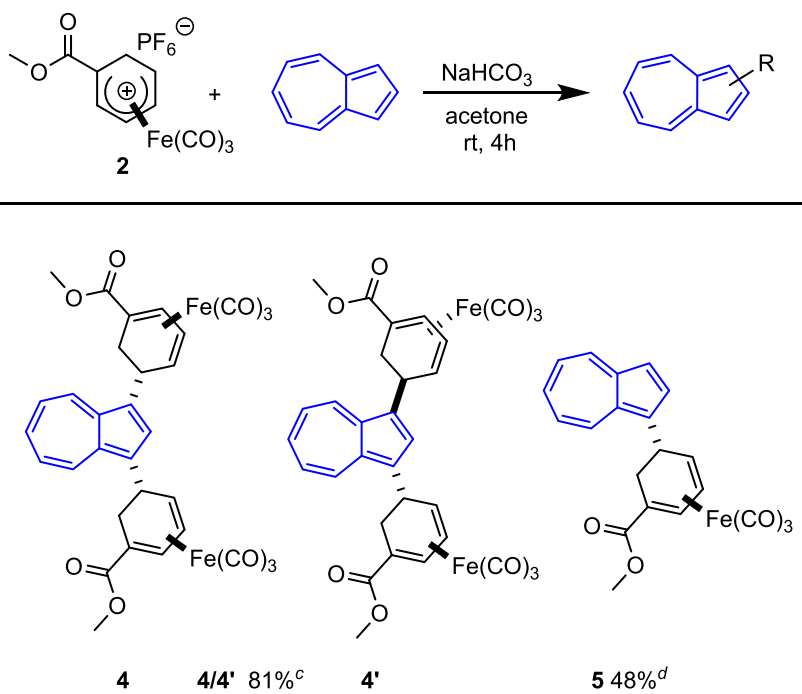

${ }^{a}$ Products are racemic with the relative stereochemistry shown ${ }^{b}$ Isolated yields. ${ }^{c}$ Excess of 2 ( 2.2 equiv), 4 equiv $\mathrm{NaHCO}_{3} \cdot{ }^{d}$ Excess of azulene (5 equiv), 2 equiv $\mathrm{NaHCO}_{3}$.

The scope of the transformation was then explored further. In addition to the activated complex (2), electronically neutral 6 and deactivated complex 7 were also selected for evaluation as electrophiles in the reaction (Figure 1).

Azulenes with extended $\pi$-systems are of interest for optoelectronic applications, as the properties of azulene can be tuned by extension of the conjugated system. ${ }^{4 c}$ Routes to

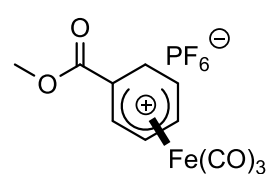

2

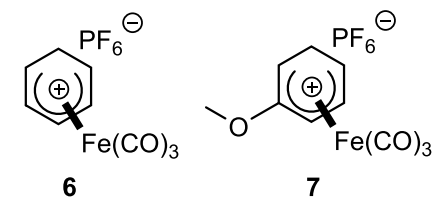

7
Figure 1. Cationic iron carbonyl dienyl complexes 2, 6, and 7, selected as electrophilic coupling partners. 
functionalizing these types of motifs could thus be valuable. A selection of 1-substituted azulene nucleophiles (8-11, Figure 2 ), as well as a 6-substituted azulene (12), was prepared and explored in reactions with iron complexes 6 and 7.<smiles></smiles>

8

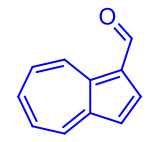

11

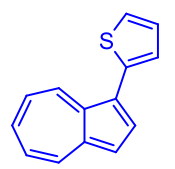

9

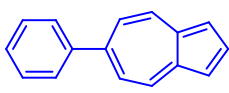

12
Figure 2. Scope of azulene nucleophiles with extended $\pi$-systems.

Azulene is significantly more expensive than guaiazulene. As nucleophiles 8-11 were prepared from azulene itself, they were used as the limiting reagent in the ensuing reactions. The results of their reaction with electrophiles 6 or 7 are shown in Scheme 4. Treating 1-phenylazulene 8 with 1.1 equiv of iron complex 6 resulted in the formation of $\mathbf{1 3}$ in an excellent yield of $95 \%$. The less activated iron complex 7 was equally effective with the same nucleophile, resulting in $94 \%$ of adduct 14 . Azulene 9, with a thienyl functionality, reacted with 6 to form compound $\mathbf{1 5}$ in a $73 \%$ yield. No other coupling products were detected, indicating that the thiophene unit does not compete with azulene as a nucleophile in this case. Azulene 10, with a pendant alkyne group, and formylated azulene $\mathbf{1 1}$ afforded adducts 16 and 17 in 70 and 50\% yields, respectively. These products contain functional handles, which can be utilized for further derivatization. As in the case of azulene, 6-phenylazulene 12 possesses two nucleophilic sites and could be doubly alkylated using an excess of the cationic iron complex $\mathbf{6}$, giving rise to an equimolar mixture of diastereomers 18 and $18^{\prime}$ in an $83 \%$ yield.

Naturally occurring guaiazulene (1) is an FDA-approved additive in cosmetics. ${ }^{26}$ Being a large-scale commercial product, it is inexpensive and readily available and therefore of special interest for synthetic applications. In addition to guaiazulene itself, seven guaiazulene derivatives (19-25) with different substitution patterns on the five-membered ring were prepared to be used as nucleophiles in the addition reaction. Substituents included both electron-withdrawing and electrondonating groups, along with some potentially useful synthetic handles in the form of a boronic ester or a halogen (Figure 3).

Addition of the guaiazulene nucleophiles 1 and 19-25 was performed using the optimized conditions shown in Table 1. The results are summarized in Scheme 5. Addition of guaiazulene itself to electrophilic iron complex 2 proceeded to give addition product 3 in an excellent yield of $97 \%$. Complexes 6 and 7 were less reactive, but upon extending the reaction time from 4 to $16 \mathrm{~h}$, alkylated azulenes 26 and 27 were obtained in yields of $98 \%$ and $93 \%$, respectively. A deactivating effect was seen for the more electron-deficient 1formyl-substituted guaiazulene derivative 19, where compound 28 was produced in a $56 \%$ yield. The coupling reaction proved to be sensitive toward substituents in the 2-position of the guaiazulene scaffold. Guaiazulene derivative 20, with a boronic
Scheme 4. Alkylation of Azulene Nucleophiles $8-12^{a, b}$
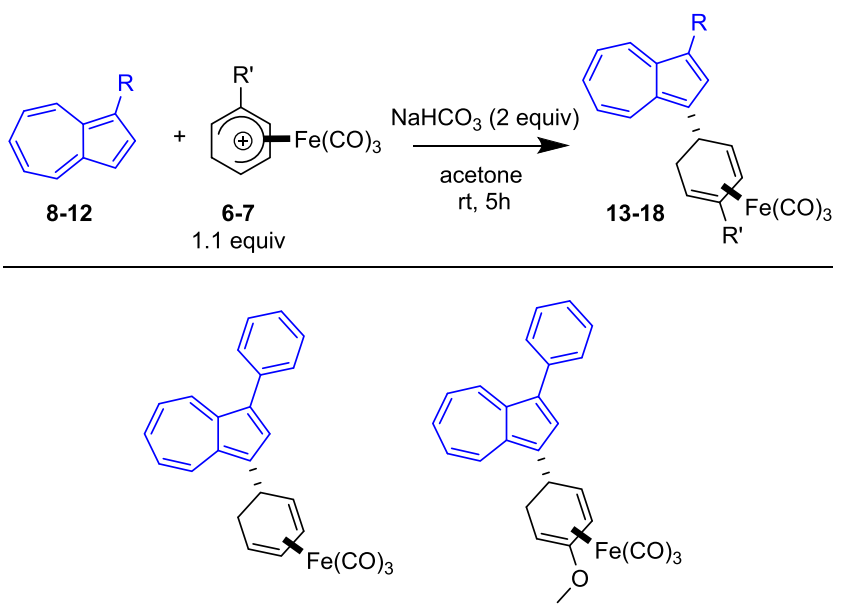

$1395 \%$

$1494 \%$

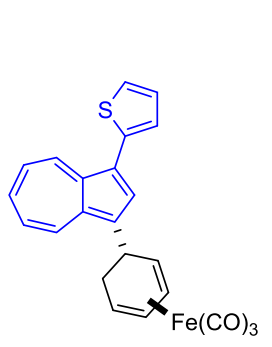

$1573 \%$

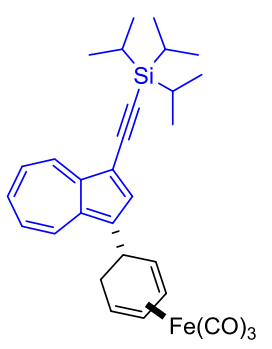

$1670 \%$

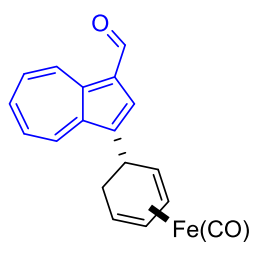

$1750 \%{ }^{c}$

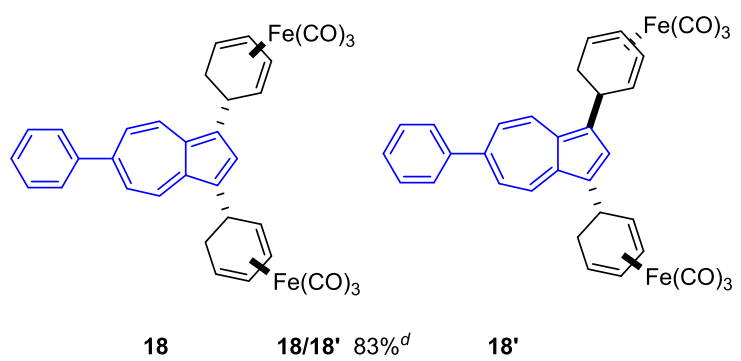

${ }^{a}$ Products are racemic with the relative stereochemistry shown. ${ }^{b}$ Isolated yields. ${ }^{c} 16 \mathrm{~h}$ reaction time. ${ }^{{ }^{d}} 2.2$ equiv electrophile, 4 equiv $\mathrm{NaHCO}_{3}$

ester in the 2-position, reacted with iron complex 2 to produce 29 in a $43 \%$ yield. 2-Iodoguaiazulene (21) reacted sluggishly, but a $63 \%$ yield of 30 could be attained using a reaction time of $16 \mathrm{~h}$ and an excess of cation 2 . The bromo-substituted guaiazulene 22 showed a higher reactivity, resulting in $79 \%$ of product 31 under the standard reaction conditions, with a $4 \mathrm{~h}$ reaction time. This suggests that steric factors may influence the reaction outcome in the case of 2 -substituted azulenes. No reaction occurred with the tolyl-substituted derivative 23. For the coupling with 2 -aminoguaiazulene (24), competing $\mathrm{N}$ addition is a possibility. ${ }^{23}$ The reaction was unsuccessful, however; while all starting material was consumed, neither $\mathrm{C}$ or $\mathrm{N}$-addition product could be isolated. To investigate if this reaction outcome was linked to instability introduced by the amino group, compound $\mathbf{2 4}$ was acetylated to amide $\mathbf{2 5}$ and the latter was subsequently used in a coupling reaction. While ${ }^{1} \mathrm{H}$ NMR analysis of the crude product looked promising, no product could be isolated in this case. 
<smiles>Cc1ccc(C)c2cc(C(C)C)ccc12</smiles><smiles>Cc1ccc(C(C)C)cc2c(C=O)ccc1-2</smiles>

19

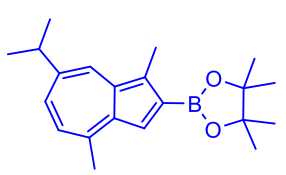

20
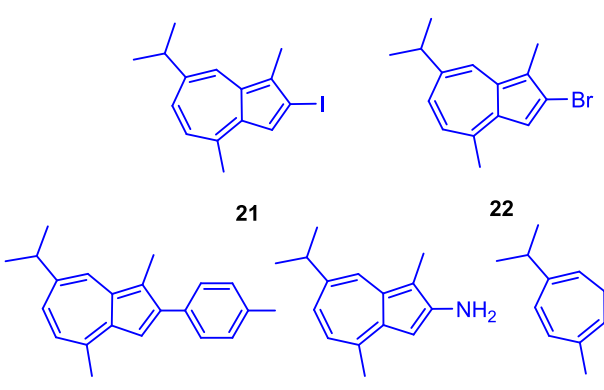

23

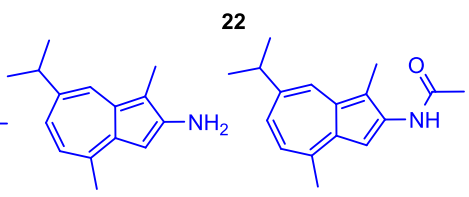

24

25
Figure 3. Guaiazulene (1) and guaiazulene derivatives evaluated as nucleophilic coupling partners in the addition to iron complexes 2,6 , and 7.

In our previous research on phenolic nucleophiles, we developed a shorter route for the coupling reaction starting from neutral iron cyclohexadiene complexes. ${ }^{25}$ This method foregoes the formation and isolation of the cationic iron carbonyl complex by forming the electrophile in situ from a neutral precursor using a catalytic amount of acid. We applied this strategy here and found that guaiazulene could be alkylated directly from the neutral iron complex 32 (precursor to cationic complex 2) in the presence of tetrafluoroboric acid (Scheme 6). When a catalytic amount of acid was used, only a small amount of product was formed. Upon increasing the amount of tetrafluoroboric acid to 1.1 equiv, however, the desired addition product 3 was obtained in an $86 \%$ yield. Using an excess of acid ( 2 equiv) lowered the yield to $45 \%$, which may be due to protonation of guaiazulene, reducing its nucleophilicity. The $86 \%$ yield obtained under the optimal conditions is higher than the combined $76 \%$ yield obtained when preforming the complex, ${ }^{25}$ followed by the addition of guaiazulene, opening up for a shorter synthetic path. As the isolation of the cationic complex includes precipitation using large amounts of solvent, this variant of the reaction can significantly reduce the amount of waste created in the synthesis of products such as 3 .

Iron carbonyl complexes are of interest as bioprobes, ${ }^{27}$ indicating that the azulenes formed in this study could be useful in their own right. In addition to a strong and distinctive absorption in the IR region from the iron carbonyl moiety, the azulene fragment introduces both a fluorophore and a clearly visible colorimetric indicator, thus potentially allowing multimodal chemical sensing. Accordingly, we investigated the UVvis, fluorescence, and IR spectroscopic properties of a representative selection of the novel compounds reported here.

Azulene derivatives are known sometimes to exhibit halochromism, i.e., to undergo changes in color upon protonation (at the azulene-1- or 3-position). ${ }^{28,29}$ Compounds $4 / 4^{\prime}, 14,26,33$, and 34 were assessed for their colorimetric responses to trifluoroacetic acid (TFA). Exposure to excess TFA (1000 equiv) resulted in each case in a color change discernible to the naked eye (Figure S67, see the Supporting Information (SI)), which became more pronounced when TFA was used as cosolvent (Figure 4). UV-vis absorption spectra of the neutral and protonated azulenes were also
Scheme 5. Alkylation of Guaiazulene-Derived Nucleophiles $^{a, b}$

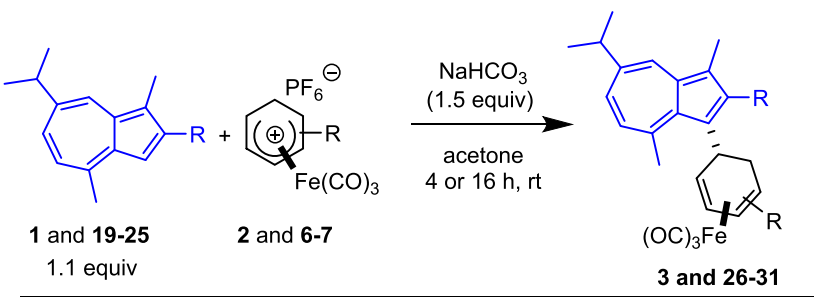

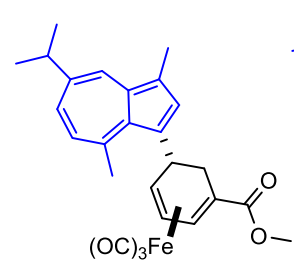

$397 c^{c}$

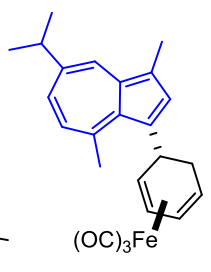

$2698 \%^{d}$

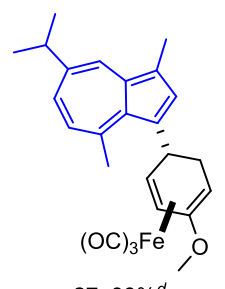

$2793 \%^{d}$

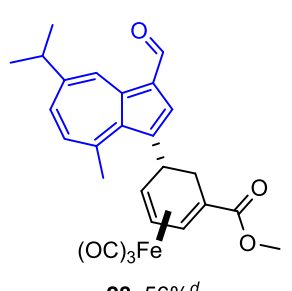

$2856 \%{ }^{d}$

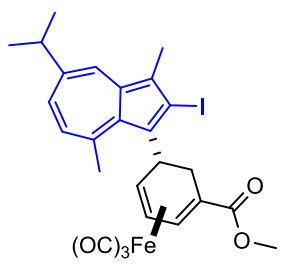

$3063 \%$,

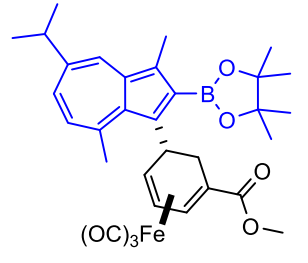

$2943 \%^{d}$

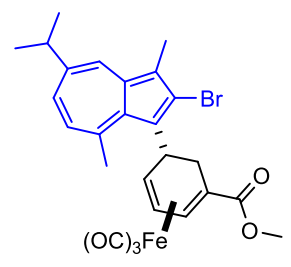

$3179 \%^{c}$

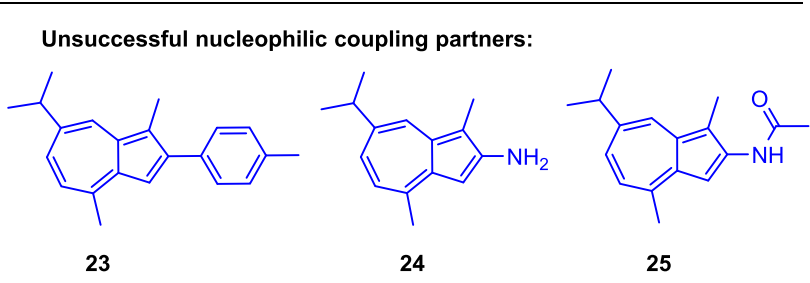

${ }^{a}$ Products are racemic with the relative stereochemistry shown. ${ }^{b}$ Isolated yields. ${ }^{c} 4 \mathrm{~h}$ reaction time. ${ }^{d} 16 \mathrm{~h}$ reaction time. ${ }^{e}$ Excess of 2 (1.1 equiv).

acquired (Figure S68). The relationship between azulene substitution pattern and halochromism has been studied and a trend can be determined. It has been shown that for some strongly halochromic azulenes with a particular substituent at the 2- or 6-position, moving the substituent to the 1- or 3position may significantly attenuate the halochromic response. $^{28 \mathrm{~b}-\mathrm{g}}$ This may be due to the change in connectivity resulting in a different preferred site of protonation. The tricarbonyliron(diene)-substituted azulenes $4 / 4^{\prime}, 14$, and 26 exhibit pronounced halochromism regardless of the fact the substituents are at 1- and 3-positions of the azulene core. This suggests that in $4 / 4^{\prime}, 14$, and 26 , the azulene core remains the 
Scheme 6. Formation of Addition Product Directly from Neutral Hydroxylated Iron Carbonyl Diene Complex $32^{a}$

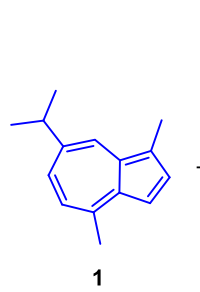

1.5 equiv
32

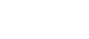

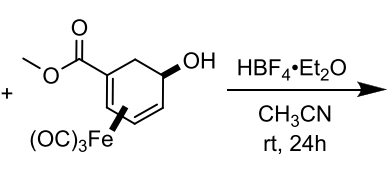

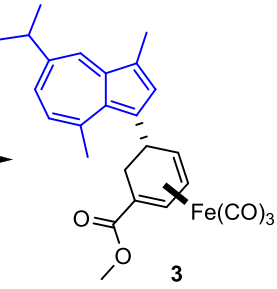

0.1 equiv $\mathrm{HBF}_{4}: 10 \%$ 1.1 equiv $\mathrm{HBF}_{4}: 86 \%$ 2 equiv $\mathrm{HBF}_{4}: 45 \%$
${ }^{a}$ Isolated yields.

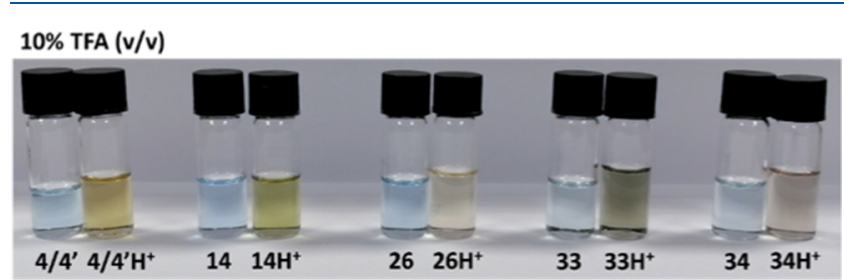

Figure 4. Azulenes $(0.5 \mathrm{mM})$ in $\mathrm{CHCl}_{3}$ (left) and TFA/ $\mathrm{CHCl}_{3} 1: 9 \mathrm{v} /$ $\mathrm{v}$ (right). Photo taken $30 \mathrm{~min}$ after sample preparation.

preferred site of protonation, as opposed to the tricarbonyliron(diene) motif.

It is known that for many azulenes, protonation can induce a significant fluorescence turn-on response, ${ }^{30}$ whereas fluorescence properties of tricarbonyliron(diene) complexes have been studied only rarely. ${ }^{27 a}$ Exposure to UV irradiation is an established method of cleaving $\mathrm{Fe}-\mathrm{C}$ bonds in tricarbonyliron(diene) complexes (see below), but the reaction time required for this process is $>3$ orders of magnitude greater than the acquisition time for a fluorescence spectrum (days vs seconds). On the basis of this semiquantitative consideration, we reasoned that fluorescence spectra could nevertheless be acquired. Compounds 4/4', 14, 26, 33, and 34 were all found to exhibit significant fluorescence enhancement upon addition of TFA, with $4 / 4^{\prime}$ showing the greatest turn-on response $\left(\lambda_{\mathrm{ex}}=266 \mathrm{~nm}, \lambda_{\mathrm{em}}=336 \mathrm{~nm}\right.$; Figure 5), and our current findings show that the tricarbonyliron(diene) motif does not quench the fluorescence of the pendent azulenium fluorophore. A titration of azulene $4 / 4^{\prime}$ with TFA was also performed, monitored by UV-vis and fluorescence spectroscopy (Figures S69 and S70). A weak second emission maximum was observed at higher acid concentrations, implying a possible further reaction under these conditions.

Iron carbonyl diene complexes exhibit strong vibrational absorption bands in the $2100-1800 \mathrm{~cm}^{-1}$ region, a window where most biological media are transparent. ${ }^{27 a, 31}$ This makes them interesting in applications such as bioimaging using midIR and Raman spectroscopy. ${ }^{31 b}$ Iron carbonyl diene complexes substituted with fluorescent coumarin moieties have been suggested as IR-fluorescent probes, ${ }^{27 a}$ and we therefore envision that the azulene-functionalized iron carbonyl complexes could be useful for similar applications. The IRabsorption spectra of the azulene addition products were measured using attenuated total reflection (ATR)-Fourier transform infrared (FTIR) in the neat state. As expected, characteristic strong peaks in the $2100-1900 \mathrm{~cm}^{-1}$ region were observed for all products possessing the iron carbonyl moiety.

To increase the synthetic utility of the formed products, we investigated the oxidative removal of the iron carbonyl moiety. Several methods have been developed for this transformation, where strong oxidative conditions are generally used, including the use of hydrogen peroxide in aqueous sodium hydroxide, ${ }^{32}$ cerium ammonium nitrate, ${ }^{33}$ trimethylamine $N$-oxide, ${ }^{34}$ or cupric chloride. ${ }^{35}$ Initial application of these methods, however, showed that these conditions were too harsh for these compounds, resulting in poor yields, partial degradation of the oxidatively sensitive azulenes, and in some cases partial aromatization of the formed cyclohexadiene. Successful demetallation of the addition products could, however, be achieved by applying mild, photolytic decomplexation conditions, using a modification of a procedure reported by Knölker. ${ }^{36}$ Irradiation of an acetonitrile solution of 13 with a low-energy UV light $(370 \mathrm{~nm}, 15 \mathrm{~W})$ for $72 \mathrm{~h}$, in the presence of air, yielded the free diene $\mathbf{3 3}$ in a $78 \%$ yield (Scheme 7 , entry 1). An advantage of the current procedure is that the demetallation can be carried out without the need for specialized equipment. However, it is likely that the reaction time can be significantly shortened with a more powerful light source. Notably, this photolytic decomplexation is more tolerant toward oxidatively labile groups than traditional
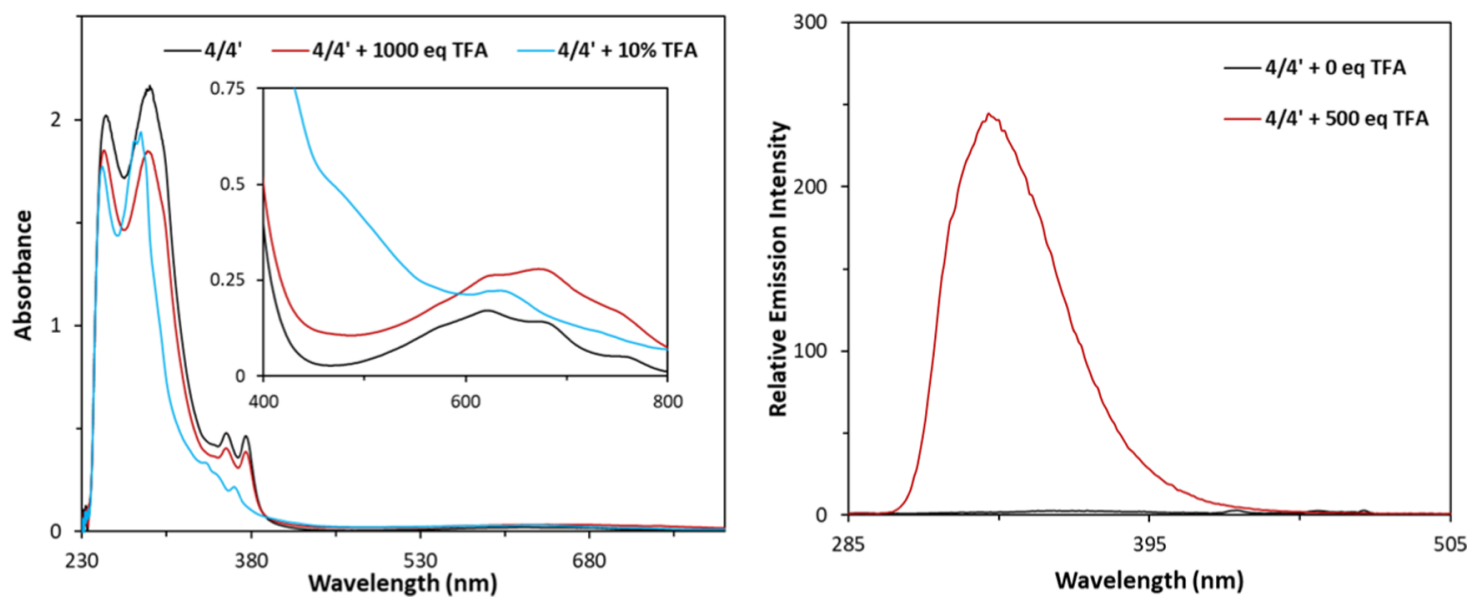

Figure 5. Response of azulene $4 / 4^{\prime}$ to the addition of TFA in $\mathrm{CHCl}_{3}$. (Left) UV-vis spectra of $4 / 4^{\prime}(50 \mu \mathrm{M})$ before and after the addition of TFA

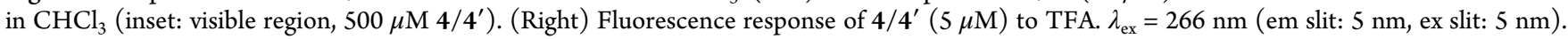


Scheme 7. Photolytic Decomplexation of Addition Products $^{a}$<smiles></smiles>

13

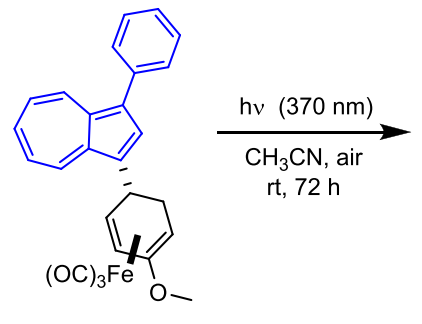

14<smiles>COC1=CCC(c2cc(C)c3cc(C(C)C)ccc(C)c2-3)C=C1</smiles>

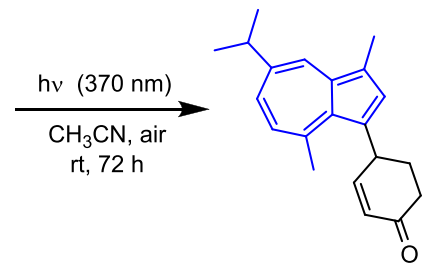

27<smiles>C1=CCC(C2=C(c3ccccc3)C(c3ccccc3)=C2)C=C1</smiles>

$3378 \%$
(2)

${ }^{a}$ Isolated yields.

methods. The free diene could also be liberated without concomitant aromatization. This has previously proved to be difficult for iron complexes possessing an aromatic substituent, which is not conjugated to the diene. ${ }^{25,37}$ Photolytic demetallation of the methoxy-substituted adduct 14 instead resulted in the formation of unsaturated ketone 34 in a $74 \%$ yield (Scheme 7 , entry 2). This type of reactivity is known upon decomplexation of 2-methoxy-substituted iron carbonyl cyclohexadiene complexes ${ }^{38}$ and provides access to a different compound class in terms of substituted azulenes. Guaiazulenederived adduct $\mathbf{2 7}$ could also be demetallated (Scheme 7, entry 3 ), affording the unsaturated ketone 35 in a $42 \%$ yield.

Another product class could be accessed by oxidative aromatization of diene 33 using 2,3-dichloro-5,6-dicyano-1,4benzoquinone (DDQ), producing 1,3-diphenylazulene (36) in an $82 \%$ yield (Scheme 8 ).

Scheme 8. Aromatization of Free Diene

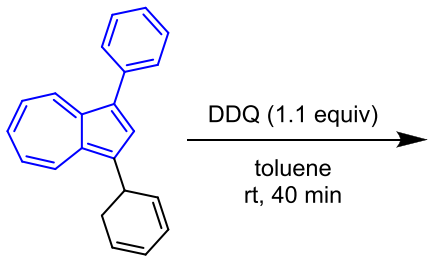

33

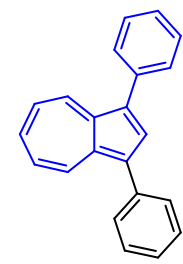

$3682 \%$
The C-4 methyl group of guaiazulene is acidic. Upon deprotonation, the formed anion is stabilized via conjugation with the electron-poor seven-membered ring. This has been utilized for condensation reactions with aldehydes under basic conditions. ${ }^{28 a, 39}$ Limited examples of conjugate additions have also been reported in this context. ${ }^{40}$ Demetallated guaiazulene derivative 35 possesses an unsaturated ketone moiety in close proximity to the C-4 methyl group, which could allow for an intramolecular conjugate addition. We were pleased to see that the treatment of $\mathbf{3 5}$ with $t$-BuOK in tetrahydrofuran (THF) at $0{ }^{\circ} \mathrm{C}$ yielded a tetracyclic product 37 in a $39 \%$ yield (Scheme 9). A strong nuclear Overhauser effect (NOE) interaction

\section{Scheme 9. Base-Mediated Cyclization of Demetallated Guaiazulene Derivative 35 Forming Tetracycle $37^{a, b}$}

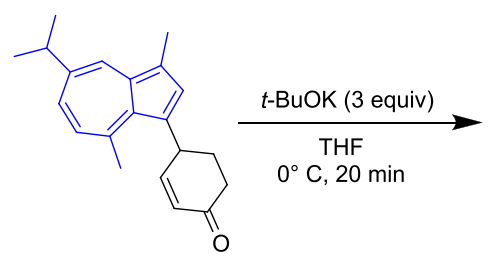

35

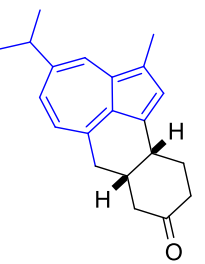

$3739 \%$
${ }^{a}$ Isolated yields. ${ }^{b}$ Product 37 is racemic with the relative stereochemistry shown.

between the two ring-junction protons indicates a cis-fused ring system. The formed tetracyclic compound possesses an unusual $6 / 6 / 5 / 7$ ring system, similar to the carbon skeleton of swinhoeisterols, isolated from the marine sponge Theonella swinhoei. ${ }^{41}$ Swinhoeisterols have been reported to have cytotoxic properties ${ }^{41}$ and have recently been the target of a total synthesis. ${ }^{42} \mathrm{We}$ therefore envision that tetracyclic structures of this type could be of interest in the synthesis of natural products and bioactive compounds. A photoswitch incorporating guaiazulene and cyclohexene was recently reported by Hecht and co-workers, and compounds such as 35 and 37 may find additional applications in this area. ${ }^{5}$

\section{CONCLUSIONS}

Azulenes are here shown to be competent nucleophiles in the addition to cationic iron carbonyl dienyl complexes with different electronic properties. The reaction proceeds smoothly at room temperature with acetone as the solvent, using an inexpensive base $\left(\mathrm{NaHCO}_{3}\right)$ as the only additive. Apart from azulene itself, functionalized azulenes with extended conjugated systems, as well as derivatives of naturally occurring guaiazulene, were evaluated as nucleophiles affording the targeted products in a $43-98 \%$ yield. Photolytic decomplexation allowed the oxidative removal of iron under mild conditions. The synthetic utility of the formed azulenes was demonstrated via further transformations, including the formation of a tetracyclic product. UV-vis and fluorescence properties of selected products were also explored, displaying some unusual halochromic properties. In conclusion, we believe that the reported methodology provides a valuable new method for azulene derivatization and could find applications in areas such as optoelectronics, sensors, pharmaceuticals, and natural product synthesis. 


\section{EXPERIMENTAL SECTION}

General Considerations. 1-(Azulen-1-yl) tetrahydrothiophenium hexafluorophosphate, ${ }^{17 \mathrm{~d}}$ neutral iron carbonyl complex $32,{ }^{25}$ cationic iron carbonyl complexes $2,{ }^{25} \mathbf{6}^{43}$ and $7^{44}$ (starting from commercial 1-methoxy-1,3-cyclohexadiene, technical grade $65 \%)$, and guaiazulene derivatives $\mathbf{1 1},{ }^{45} \mathbf{1 2},{ }^{46} \mathbf{1 9},{ }^{12} \mathbf{2 0}-\mathbf{2 2},{ }^{47}$ and $23^{48}$ were synthesized according to literature procedures. All other solvents and reagents were purchased from commercial suppliers and used without purification or drying, unless otherwise stated. Photocatalytic decomplexation was performed using a low-energy black light lamp (Velleman lighting, $15 \mathrm{~W}, 850 \mathrm{~lm}$ ). Structural assignments were made with additional information from gradient correlation spectroscopy (gCOSY), gradient heteronuclear single-quantum coherence (gHSQC), nuclear Overhauser enhancement spectroscopy (NOESY), and gradient heteronuclear multiple-bond correlation (gHMBC) experiments.

Analytical Methods. Column chromatography was performed on a Biotage Isolera Spektra One with Biotage SNAP KP-sil (silica gel) or KP-C18-HS (C18, reverse phase) columns. NMR spectra, ${ }^{1} \mathrm{H}$ NMR and ${ }^{13} \mathrm{C}$ NMR, were recorded on an Agilent $400 \mathrm{MHz}(101$ $\mathrm{MHz}$ for ${ }^{13} \mathrm{C}$ NMR). The chemical shifts for ${ }^{1} \mathrm{H}$ and ${ }^{13} \mathrm{C}$ NMR spectra are reported in parts per million ( $\mathrm{ppm}$ ) using the residual solvent peak for reference. The following abbreviations are used for reporting NMR peaks: singlet $(\mathrm{s})$, doublet $(\mathrm{d})$, triplet $(\mathrm{t})$, quartet $(\mathrm{q})$, heptet (hept), multiplet (m), broad (br), and apparent (app). All coupling constants $(J)$ are reported in hertz $(\mathrm{Hz})$. For diastereomeric mixtures, peaks that can be attributed to single diastereomers are labeled $d_{1} / d_{2}$. ATR-FTIR spectra were recorded on a PerkinElmer Spectrum Frontier infrared spectrometer with a pike-GladiATR module and reported in wavenumber $\left(\mathrm{cm}^{-1}\right)$. Melting points were recorded on a Büchi Melting Point B-545. High-resolution mass spectrometry (HRMS) was performed on an Agilent 1290 infinity LC system equipped with an autosampler tandem to an Agilent 6520 Accurate Mass Q-TOF LC/MS. ${ }^{29 a}$ Fluorescence spectra were acquired on an Agilent Technologies Cary Eclipse fluorescence spectrophotometer. UV-vis spectra were acquired on a PerkinElmer Lambda20 Spectrophotometer, using a Starna Silica (quartz) cuvette with $10 \mathrm{~mm}$ path length, two faces polished.

General Procedure A: Addition of Guaiazulene-Derived Nucleophiles to Cationic Iron Carbonyl Complexes. Cationic iron carbonyl complex (1.0 equiv), guaiazulene derivative (1.1 equiv), $\mathrm{NaHCO}_{3}$ (1.5 equiv), and acetone $(2.0 \mathrm{~mL}$ ) were added to a $5 \mathrm{~mL}$ microwave vial equipped with a stir bar. The vial was capped and stirred at room temperature for 4 or $16 \mathrm{~h}$. The crude reaction mixture was diluted with diethyl ether $(5.0 \mathrm{~mL})$, filtered through a pad of basic aluminum oxide, concentrated under a stream of $\mathrm{N}_{2}$ gas, and purified by reversed-phase flash column chromatography $(\mathrm{MeOH} /$ $\mathrm{H}_{2} \mathrm{O}$ ).

General Procedure B: Addition of Azulene-Derived Nucleophiles to Cationic Iron Carbonyl Complexes. Azulene derivative (1.0 equiv), cationic iron carbonyl complex (1.1 equiv), $\mathrm{NaHCO}_{3}(2.0$ equiv), and acetone $(1.0 \mathrm{~mL})$ were added to a $5 \mathrm{~mL}$ microwave vial equipped with a stir bar. The vial was capped and stirred at room temperature for $5 \mathrm{~h}$. The crude reaction mixture was diluted with diethyl ether $(3.0 \mathrm{~mL})$, filtered through a pad of silica, concentrated under a stream of $\mathrm{N}_{2}$ gas, and purified by flash column chromatography.

Tricarbonyl[methyl 5-(5-isopropyl-3,8-dimethylazulen-1yl)cyclohexa-1,3-diene-1-carboxylate]iron (3). Starting from Cationic Iron Carbonyl Complex 2. Synthesized according to general procedure A using iron complex $2(42.2 \mathrm{mg}, 0.100 \mathrm{mmol})$, guaiazulene $1(21.8 \mathrm{mg}, 0.110 \mathrm{mmol})$, and $\mathrm{NaHCO}_{3}(12.6 \mathrm{mg}$, $0.150 \mathrm{mmol}$ ), with a reaction time of $4 \mathrm{~h}$. The product was purified by reversed-phase chromatography $\left(\mathrm{MeOH} / \mathrm{H}_{2} \mathrm{O}, 60: 40 \rightarrow\right.$ 85:15), yielding 3 as a blue solid (47.4 mg, 97\%).

Starting from Neutral Iron Carbonyl Complex 32. Iron complex $32(30.0 \mathrm{mg}, 0.102 \mathrm{mmol})$ and guaiazulene $1(30.3 \mathrm{mg}, 0.153 \mathrm{mmol})$ were added to a $5 \mathrm{~mL}$ microwave vial equipped with a stir bar. Acetonitrile $(1.0 \mathrm{~mL})$ containing tetrafluoroboric acid diethyl ether complex (15.3 $\mu \mathrm{L}, 0.112 \mathrm{mmol})$ was added, and the vial was capped and stirred at room temperature for $24 \mathrm{~h}$. The reaction mixture was diluted with diethyl ether, filtered through a pad of basic aluminum oxide, and the solvent was evaporated under a stream of $\mathrm{N}_{2}$ gas. Purification by flash column chromatography yielded 3 as a blue solid (41.7 mg, 86\%); mp 46-47 ${ }^{\circ} \mathrm{C}$; ${ }^{1} \mathrm{H}$ NMR (400 MHz, chloroform-d) $\delta 8.02(\mathrm{~d}, J=2.2 \mathrm{~Hz}, 1 \mathrm{H}), 7.46(\mathrm{~s}, 1 \mathrm{H}), 7.24(\mathrm{dd}, J=10.6,2.2 \mathrm{~Hz}$, $1 \mathrm{H}), 6.83(\mathrm{~d}, J=10.6 \mathrm{~Hz}, 1 \mathrm{H}), 6.31(\mathrm{dd}, J=4.4,0.8 \mathrm{~Hz}, 1 \mathrm{H}), 5.56$ $(\mathrm{dd}, J=6.4,4.4 \mathrm{~Hz}, 1 \mathrm{H}), 4.56(\mathrm{app} \mathrm{dt}, J=11.3,3.9 \mathrm{~Hz}, 1 \mathrm{H}), 3.73(\mathrm{~s}$ $3 \mathrm{H}$ ), 3.44 (ddd, $J=6.5,3.3,1.4 \mathrm{~Hz}, 1 \mathrm{H}$ ), 3.00 (hept, $J=6.9 \mathrm{~Hz}, 1 \mathrm{H}$ ), $2.96(\mathrm{~s}, 3 \mathrm{H}), 2.87(\mathrm{dd}, J=15.2,11.3 \mathrm{~Hz}, 1 \mathrm{H}), 2.59(\mathrm{~s}, 3 \mathrm{H}), 1.60$ (ddd, $J=15.2,4.3,0.9 \mathrm{~Hz}, 1 \mathrm{H}), 1.32(\mathrm{~d}, J=6.9 \mathrm{~Hz}, 6 \mathrm{H}) ;{ }^{13} \mathrm{C}\left\{{ }^{1} \mathrm{H}\right\}$ NMR (101 MHz, chloroform-d) $\delta 172.6,144.5,139.7,138.5,136.4$, $134.5,133.7,131.8,130.9,126.8,124.9,88.7,84.7,69.1,62.8,51.6$, 39.4, 37.6, 33.7, 27.4, 24.5, 13.1. Signal for $\mathrm{Fe}-\mathrm{CO}$ not seen; FTIRATR $\nu_{\max } / \mathrm{cm}^{-1} 2053(\mathrm{Fe}-\mathrm{CO}), 1975(\mathrm{Fe}-\mathrm{CO}), 1705(\mathrm{C}=\mathrm{O})$; HRMS (ESI+) $m / z$ : $[\mathrm{M}+\mathrm{H}]^{+}$calcd for $\mathrm{C}_{26} \mathrm{H}_{27} \mathrm{FeO}_{5}$ 475.1208; found 475.1199.

Hexacarbonyl[dimethyl 5,5'-(azulene-1,3-diyl)bis(cyclohexa-1,3-diene-1-carboxylate)]diiron (4/4'). Synthesized according to general procedure B using azulene $(12.9 \mathrm{mg}, 0.101$ $\mathrm{mmol})$, iron complex 2 (93.4 mg, $0.221 \mathrm{mmol})$, and $\mathrm{NaHCO}_{3}(33.8$ $\mathrm{mg}, 0.403 \mathrm{mmol}$ ). The product was purified by reversed-phase flash chromatography $\left(\mathrm{MeOH} / \mathrm{H}_{2} \mathrm{O}\right.$ 85:15), yielding an equimolar mixture of diastereomers 4 and $4^{\prime}$ as a blue-green amorphous solid $(55.1 \mathrm{mg}$, $81 \%)$; ${ }^{1} \mathrm{H}$ NMR (400 MHz, chloroform- $d$ ) $\delta 8.14$ and $8.13\left(d_{1} / d_{2}\right)$ $(\mathrm{d}, J=9.6 \mathrm{~Hz}, 2 \mathrm{H}), 7.50($ app t, $J=9.8 \mathrm{~Hz}, 1 \mathrm{H}), 7.41$ and $7.38\left(d_{1} /\right.$ $\left.d_{2}\right)(\mathrm{s}, 1 \mathrm{H}), 7.02$ and $7.02\left(d_{1} / d_{2}\right)($ app t, $J=9.9 \mathrm{~Hz}, 2 \mathrm{H}), 6.35-6.31$ $(\mathrm{m}, 2 \mathrm{H}), 5.53$ and $5.48\left(d_{1} / d_{2}\right)(\mathrm{dd}, J=6.4,4.4 \mathrm{~Hz}, 2 \mathrm{H}), 4.19-4.09$ $(\mathrm{m}, 2 \mathrm{H}), 3.75$ and $3.74\left(d_{1} / d_{2}\right)(\mathrm{s}, 6 \mathrm{H}), 3.44$ and 3.40 (ddd, $J=6.4$, $3.5,1.4 \mathrm{~Hz}, 2 \mathrm{H}), 2.95$ and $2.93\left(d_{1} / d_{2}\right)(\mathrm{dd}, J=15.2,11.4 \mathrm{~Hz}, 2 \mathrm{H})$, 1.66 and $1.59\left(d_{1} / d_{2}\right)(\mathrm{dd}, J=15.4,4.0 \mathrm{~Hz}, 2 \mathrm{H}) ;{ }^{13} \mathrm{C}\left\{{ }^{1} \mathrm{H}\right\} \operatorname{NMR}(101$ $\mathrm{MHz}$, chloroform-d) $\delta 210.2$ (br), 172.7, 172.6, 138.4, 138.4, 135.6, $135.5,133.5,133.5,133.2,133.1,131.6,131.4,121.9,121.8,89.2$, 89.2, 84.5, 67.6, 67.4, 63.0, 62.9, 51.9, 37.2, 37.1, 32.8, 32.6; FTIRATR $\nu_{\max } / \mathrm{cm}^{-1} 2048(\mathrm{Fe}-\mathrm{CO}), 1967(\mathrm{Fe}-\mathrm{CO}), 1703(\mathrm{C}=\mathrm{O})$; HRMS (ESI+) $m / z:[\mathrm{M}+\mathrm{H}]^{+}$calcd for $\mathrm{C}_{32} \mathrm{H}_{25} \mathrm{Fe}_{2} \mathrm{O}_{10}$ 681.0147; found 681.0139 .

Tricarbonyl[methyl 5-(azulen-1-yl)cyclohexa-1,3-diene-1carboxylate]iron (5). Synthesized according to general procedure B, using iron complex $2(21.1 \mathrm{mg}, 0.0500 \mathrm{mmol})$ and azulene $(32.0$ $\mathrm{mg}, 0.250 \mathrm{mmol}$ ). The product was purified by reversed-phase flash chromatography (methanol/water, 80:20 $\rightarrow$ 90:10), yielding 5 as a blue sticky solid ( $9.7 \mathrm{mg}, 48 \%) ;{ }^{1} \mathrm{H}$ NMR $(400 \mathrm{MHz}$, chloroform- $d$ ) $\delta$ $8.26(\mathrm{~d}, J=9.1 \mathrm{~Hz}, 1 \mathrm{H}), 8.23(\mathrm{~d}, J=8.7 \mathrm{~Hz}, 1 \mathrm{H}), 7.70(\mathrm{~d}, J=3.9 \mathrm{~Hz}$, $1 \mathrm{H}), 7.55$ (app t, $J=9.9 \mathrm{~Hz}, 1 \mathrm{H}), 7.29(\mathrm{~d}, J=4.0 \mathrm{~Hz}, 1 \mathrm{H}), 7.12(\mathrm{app}$ $\mathrm{t}, J=9.8 \mathrm{~Hz}, 1 \mathrm{H}), 7.08($ app t $, J=9.7 \mathrm{~Hz}, 1 \mathrm{H}), 6.30(\mathrm{ddd}, J=4.4,1.4$ $0.9 \mathrm{~Hz}, 1 \mathrm{H}), 5.51(\mathrm{dd}, J=6.4,4.4 \mathrm{~Hz}, 1 \mathrm{H}), 4.20(\mathrm{app} \mathrm{dt}, J=11.4,3.7$ $\mathrm{Hz}, 1 \mathrm{H}), 3.73(\mathrm{~s}, 3 \mathrm{H}), 3.46(\mathrm{ddd}, J=6.4,3.5,1.4 \mathrm{~Hz}, 1 \mathrm{H}), 2.97$ (ddd, $J=15.3,11.4,0.9 \mathrm{~Hz}, 1 \mathrm{H}), 1.67$ (ddd, $J=15.4,3.9,0.9 \mathrm{~Hz}, 1 \mathrm{H}$ ); ${ }^{13} \mathrm{C}\left\{{ }^{1} \mathrm{H}\right\}$ NMR (101 MHz, chloroform-d) $\delta 172.6,141.1,137.9$, 137.0, 134.7, 134.7, 134.4, 133.1, 122.8, 122.0, 117.2, 89.3, 84.6, 67.7, 63.1, 51.8, 37.2, 32.9. Signal for Fe-CO not seen; FTIR-ATR $\nu_{\max } /$ $\mathrm{cm}^{-1} 2047$ ( $\left.\mathrm{Fe}-\mathrm{CO}\right), 1969$ (Fe-CO), $1711(\mathrm{C}=\mathrm{O})$; HRMS (ESI+) $m / z:[\mathrm{M}+\mathrm{H}]^{+}$calcd for $\mathrm{C}_{21} \mathrm{H}_{17} \mathrm{FeO}_{5}$ 405.0425; found 405.0424.

1-Phenylazulene (8). Synthesized according to a literature procedure. ${ }^{17 \mathrm{~d}}$ To a Radleys Carousel reaction tube equipped with a stirrer was added 1-(azulen-1-yl) tetrahydrothiophenium hexafluorophosphate (500 mg, $1.39 \mathrm{mmol})$, phenylboronic acid (203 mg, 1.67 $\mathrm{mmol}), \mathrm{K}_{3} \mathrm{PO}_{4}(589 \mathrm{mg}, 2.78 \mathrm{mmol})$, Xphos $(60.2 \mathrm{mg}, 0.139 \mathrm{mmol})$, and $\mathrm{Pd}(\mathrm{OAc})_{2}(12.5 \mathrm{mg}, 0.0557 \mathrm{mmol})$. The vial was capped, evacuated, and refilled with argon. Dimethylformamide (DMF) (10 $\mathrm{mL}$ ) was added, and the vial was heated in a heating block at $75^{\circ}$ for 6 h. The crude product was diluted with water and extracted with petroleum ether, and the organic phase was washed with brine and 5\% aqueous lithium chloride. The solvent was evaporated under reduced pressure, and the crude product was purified by flash column chromatography (100\% petroleum ether), yielding 8 as a blue solid $(166.7 \mathrm{mg}, 59 \%) .{ }^{1} \mathrm{H}$ NMR $(400 \mathrm{MHz}$, chloroform- $d) \delta 8.57(\mathrm{~d}, J=$ $9.8 \mathrm{~Hz}, 1 \mathrm{H}), 8.36(\mathrm{~d}, J=9.4 \mathrm{~Hz}, 1 \mathrm{H}), 8.03(\mathrm{~d}, J=3.8 \mathrm{~Hz}, 1 \mathrm{H}), 7.65-$ $7.57(\mathrm{~m}, 3 \mathrm{H}), 7.53-7.48(\mathrm{~m}, 2 \mathrm{H}), 7.45(\mathrm{~d}, J=3.9 \mathrm{~Hz}, 1 \mathrm{H}), 7.38-$ 
$7.33(\mathrm{~m}, 1 \mathrm{H}), 7.19-7.12(\mathrm{~m}, 2 \mathrm{H}) ;{ }^{13} \mathrm{C}\left\{{ }^{1} \mathrm{H}\right\}$ NMR (101 MHz, chloroform-d) $\delta 141.8,138.3,137.7,137.4,137.3,135.8,135.4,131.5$, $129.9,128.8,126.4,123.5,123.2,117.6$. Analysis data are in accordance with published data for this compound. ${ }^{49}$

1-(2-Thienyl)-azulene (9). Synthesized according to a literature procedure. ${ }^{17 \mathrm{~d}}$ To a Radleys Carousel reduced volume reaction tube equipped with a stirrer was added 1-(azulen-1-yl) tetrahydrothiophenium hexafluorophosphate $(250 \mathrm{mg}, 0.694 \mathrm{mmol}), 2$-(thiopheneboronic acid)pinacol ester (175 mg, $0.833 \mathrm{mmol}), \mathrm{K}_{3} \mathrm{PO}_{4}(295 \mathrm{mg}, 1.39$ $\mathrm{mmol})$, Xphos (33.1 mg, $0.0694 \mathrm{mmol})$, and $\mathrm{Pd}(\mathrm{OAc})_{2}(6.2 \mathrm{mg}$, $0.028 \mathrm{mmol})$. The vial was capped, evacuated, and refilled with argon. DMF $(5.0 \mathrm{~mL})$ was added, and the vial was heated in a heating block at $75{ }^{\circ} \mathrm{C}$ for $6 \mathrm{~h}$. The crude product was diluted with water and extracted with petroleum ether, and the organic phase was washed with brine and $5 \%$ aqueous lithium chloride. The solvent was evaporated under reduced pressure, and the crude product was purified by flash column chromatography ( $100 \%$ petroleum ether), yielding 9 as a blue-green oil $(77.5 \mathrm{mg}, 53 \%) .{ }^{1} \mathrm{H}$ NMR $(400 \mathrm{MHz}$, chloroform- $d$ ) $\delta 8.77(\mathrm{~d}, J=9.8 \mathrm{~Hz}, 1 \mathrm{H}), 8.32(\mathrm{~d}, J=9.4 \mathrm{~Hz}, 1 \mathrm{H})$, $8.07(\mathrm{~d}, J=4.0 \mathrm{~Hz}, 1 \mathrm{H}), 7.64-7.67(\mathrm{~m}, 1 \mathrm{H}), 7.41(\mathrm{~d}, J=4.0 \mathrm{~Hz}$, $1 \mathrm{H}), 7.38-7.35(\mathrm{~m}, 1 \mathrm{H}), 7.32-7.29(\mathrm{~m}, 1 \mathrm{H}), 7.23-7.15(\mathrm{~m}, 3 \mathrm{H})$; ${ }^{13} \mathrm{C}\left\{{ }^{1} \mathrm{H}\right\}$ NMR (101 MHz, chloroform- $\left.d\right) \delta 142.3,139.8,138.7$, 137.5, 137.4, 135.9, 135.1, 127.8, 124.7, 124.5, 123.8, 123.7, 123.7, 117.9. Analysis data are in accordance with published data for this compound. ${ }^{50}$

(Azulen-1-ylethynyl)triisopropylsilane (10). To a microwave reaction vial was added 1 -(azulen-1-yl) tetrahydrothiophenium hexafluorophosphate $(100 \mathrm{mg}, 0.278 \mathrm{mmol}), \mathrm{CuI}(5.3 \mathrm{mg}, 0.028$ $\mathrm{mmol}$ ), $\mathrm{K}_{3} \mathrm{PO}_{4}$ (64.8 mg, $\left.0.305 \mathrm{mmol}\right), t$-BuXphos (11.8 mg, 0.0278 $\mathrm{mmol})$, and $\mathrm{Pd}(\mathrm{OAc})_{2}(3.1 \mathrm{mg}, 0.014 \mathrm{mmol})$. The vial was capped, evacuated, and refilled with argon. (Triisopropylsilyl)acetylene (94 $\mu \mathrm{L}, 0.419 \mathrm{mmol}$ ) and $2.0 \mathrm{~mL}$ DMF were added, and the vial was heated in a heating block at $80{ }^{\circ} \mathrm{C}$ for $16 \mathrm{~h}$. The crude product was diluted with water and extracted with petroleum ether. The organic phase was then washed with brine and $5 \%$ aqueous lithium chloride. The solvent was evaporated under reduced pressure, and the crude product was purified by flash column chromatography $(100 \%$ petroleum ether), yielding 10 as a blue oil $(23.7 \mathrm{mg}, 27 \%) .{ }^{1} \mathrm{H}$ NMR (400 MHz, chloroform- $d) \delta 8.59(\mathrm{~d}, J=9.6 \mathrm{~Hz}, 1 \mathrm{H}), 8.28(\mathrm{~d}, J$ $=9.4 \mathrm{~Hz}, 1 \mathrm{H}), 7.98(\mathrm{~d}, J=4.0 \mathrm{~Hz}, 1 \mathrm{H}), 7.63($ app t, $J=9.9 \mathrm{~Hz}, 1 \mathrm{H})$, $7.30-7.18(\mathrm{~m}, 3 \mathrm{H}), 1.22-1.19(\mathrm{~m}, 21 \mathrm{H}) ;{ }^{13} \mathrm{C}\left\{{ }^{1} \mathrm{H}\right\}$ NMR $(101 \mathrm{MHz}$, chloroform-d) $\delta 142.0,141.3,140.0,138.7,137.3,136.5,124.7,124.2$, $117.5,111.4,103.3,94.8,19.0,11.7$; FTIR-ATR $\nu_{\max } / \mathrm{cm}^{-1} 2133$ $(\mathrm{C} \equiv \mathrm{C})$; HRMS (ESI+) $m / z:[\mathrm{M}+\mathrm{H}]^{+}$calcd for $\mathrm{C}_{21} \mathrm{H}_{29} \mathrm{Si} 309.2033$; found 309.2048 .

Tricarbonyl[1-(cyclohexa-2,4-dien-1-yl)-3-phenylazulene]iron (13). Synthesized according to general procedure B using azulene derivative $8(20.6 \mathrm{mg}, 0.101 \mathrm{mmol})$, iron complex 6 (40.5 mg, $0.111 \mathrm{mmol})$, and $\mathrm{NaHCO}_{3}(16.9 \mathrm{mg}, 0.202 \mathrm{mmol})$. The product was purified by flash chromatography (100\% petroleum ether), yielding 13 as a blue-green solid (40.6 mg, 95\%); mp 51-55 ${ }^{\circ} \mathrm{C} ;{ }^{1} \mathrm{H}$ NMR $(400 \mathrm{MHz}$, chloroform- $d$ ) $\delta 8.41(\mathrm{dd}, J=9.7,0.9 \mathrm{~Hz}, 1 \mathrm{H}), 8.23(\mathrm{~d}, J$ $=9.5 \mathrm{~Hz}, 1 \mathrm{H}), 7.84(\mathrm{~s}, 1 \mathrm{H}), 7.61-7.56(\mathrm{~m}, 2 \mathrm{H}), 7.55-7.46(\mathrm{~m}, 3 \mathrm{H})$, 7.35 (app ddt, $J=7.9,6.8,1.3 \mathrm{~Hz}, 1 \mathrm{H}), 7.06($ app t, $J=9.8 \mathrm{~Hz}, 1 \mathrm{H})$, $7.03($ app t, $J=9.7 \mathrm{~Hz}, 1 \mathrm{H}), 5.59$ (ddd, $J=6.5,3.3,2.0 \mathrm{~Hz}, 1 \mathrm{H}), 5.46$ (ddd, $J=5.9,4.1,1.5 \mathrm{~Hz}, 1 \mathrm{H}), 4.06(\mathrm{dt}, J=11.2,3.6 \mathrm{~Hz}, 1 \mathrm{H}), 3.33$ (ddd, $J=6.4,3.6,1.4 \mathrm{~Hz}, 1 \mathrm{H}), 3.31-3.27(\mathrm{~m}, 1 \mathrm{H}), 2.57(\mathrm{ddd}, J=$ $15.2,11.1,3.8 \mathrm{~Hz}, 1 \mathrm{H}), 1.90-1.83(\mathrm{~m}, 1 \mathrm{H}) ;{ }^{13} \mathrm{C}\left\{{ }^{1} \mathrm{H}\right\}$ NMR $(101$ $\mathrm{MHz}$, chloroform-d) $\delta 212.3,138.6,137.4,136.3,136.1,135.8,134.9$, $134.9,133.5,130.3,129.9,128.8,126.5,123.1,122.0,86.4,84.7,66.9$, 60.8, 35.7, 34.3; FTIR-ATR $\nu_{\max } / \mathrm{cm}^{-1} 2035$ (Fe-CO), $1946(\mathrm{Fe}-$ CO); HRMS (ESI+) $m / z:[\mathrm{M}+\mathrm{H}]^{+}$calcd for $\mathrm{C}_{25} \mathrm{H}_{19} \mathrm{FeO}_{3} 423.0683$; found 423.0695 .

Tricarbonyl[1-(4-methoxycyclohexa-2,4-dien-1-yl)-3phenylazulene]iron (14). Synthesized according to general procedure $\mathrm{B}$ using azulene derivative $8(100 \mathrm{mg}, 0.490 \mathrm{mmol})$, iron complex 7 (212 mg, $0.539 \mathrm{mmol}$ ), and $\mathrm{NaHCO}_{3}(82.3 \mathrm{mg}, 0.979$ $\mathrm{mmol}$ ) in $4.0 \mathrm{~mL}$ acetone. The product was purified by flash chromatography (petroleum ether/ethyl acetate, 98:2), yielding 14 as a blue-green solid (209 mg, 94\%); mp 53-58 ${ }^{\circ} \mathrm{C}$; ${ }^{1} \mathrm{H}$ NMR (400
MHz, chloroform- $d$ ) $\delta 8.43(\mathrm{~d}, J=9.7 \mathrm{~Hz}, 1 \mathrm{H}), 8.23(\mathrm{~d}, J=9.7 \mathrm{~Hz}$, $1 \mathrm{H}), 7.83(\mathrm{~s}, 1 \mathrm{H}), 7.63-7.58(\mathrm{~m}, 2 \mathrm{H}), 7.57-7.49(\mathrm{~m}, 3 \mathrm{H}), 7.41-$ $7.35(\mathrm{~m}, 1 \mathrm{H}), 7.07($ app t, $J=9.8 \mathrm{~Hz}, 1 \mathrm{H}), 7.04($ app t, $J=9.8 \mathrm{~Hz}$, $1 \mathrm{H}), 5.22(\mathrm{dd}, J=6.5,2.2 \mathrm{~Hz}, 1 \mathrm{H}), 3.90($ app dt, $J=11.1,3.5 \mathrm{~Hz}$, $1 \mathrm{H}), 3.72(\mathrm{~s}, 3 \mathrm{H}), 3.56$ (app dtd, $J=3.4,2.3,0.8 \mathrm{~Hz}, 1 \mathrm{H}), 2.94$ (dd, $J$ $=6.5,3.5 \mathrm{~Hz}, 1 \mathrm{H}), 2.60(\mathrm{ddd}, J=14.8,11.1,3.7 \mathrm{~Hz}, 1 \mathrm{H}), 1.99(\mathrm{app}$ $\mathrm{dt}, J=15.2,2.9 \mathrm{~Hz}, 1 \mathrm{H}) ;{ }^{13} \mathrm{C}\left\{{ }^{1} \mathrm{H}\right\} \mathrm{NMR}(101 \mathrm{MHz}$, chloroform- $d) \delta$ $140.4,138.6,137.5,136.4,136.0,135.8,135.0,134.7,133.6,130.3$, 130.0, 128.8, 126.5, 123.1, 122.0, 66.8, 56.0, 54.6, 53.8, 35.4, 35.1, signal for $\mathrm{Fe}-\mathrm{CO}$ not seen; FTIR-ATR $\nu_{\max } / \mathrm{cm}^{-1} 2035(\mathrm{Fe}-\mathrm{CO})$, $1946(\mathrm{Fe}-\mathrm{CO})$; HRMS (ESI+) $m / z:[\mathrm{M}+\mathrm{H}]^{+}$calcd for $\mathrm{C}_{26} \mathrm{H}_{21} \mathrm{FeO}_{4}$ 453.0789; found 453.0787 .

Tricarbonyl[2-(3-(cyclohexa-2,4-dien-1-yl)azulen-1-yl)thiophene]iron (15). Synthesized according to general procedure $B$ using azulene derivative $9(10.5 \mathrm{mg}, 0.0499 \mathrm{mmol})$, iron complex 6 (20.0 mg, 0.0550), and $\mathrm{NaHCO}_{3}(8.4 \mathrm{mg}, 0.10 \mathrm{mmol})$ in $0.5 \mathrm{~mL}$ acetone. The product was purified by flash chromatography (petroleum ether/EtOAc 99:1), yielding 15 as a sticky green solid (15.6 mg, 73\%); ${ }^{1} \mathrm{H}$ NMR (400 MHz, chloroform- $d$ ) $\delta 8.61$ (d, $J=$ $9.6 \mathrm{~Hz}, 1 \mathrm{H}), 8.18(\mathrm{~d}, J=9.6 \mathrm{~Hz}, 1 \mathrm{H}), 7.86(\mathrm{~s}, 1 \mathrm{H}), 7.53($ app t, $J=$ $9.8 \mathrm{~Hz}, 1 \mathrm{H}), 7.36(\mathrm{dd}, J=5.1,1.2 \mathrm{~Hz}, 1 \mathrm{H}), 7.25(\mathrm{dd}, J=3.6,1.2 \mathrm{~Hz}$, $1 \mathrm{H}), 7.18(\mathrm{dd}, J=5.1,3.5 \mathrm{~Hz}, 1 \mathrm{H}), 7.07$ (app t, $J=9.8 \mathrm{~Hz}, 1 \mathrm{H}), 7.06$ (app t, $J=9.8 \mathrm{~Hz}, 1 \mathrm{H}), 5.63-5.58(\mathrm{~m}, 1 \mathrm{H}), 5.48(\mathrm{ddd}, J=6.0,4.1$, $1.5 \mathrm{~Hz}, 1 \mathrm{H}), 4.02(\mathrm{app} \mathrm{dt}, J=11.1,3.6 \mathrm{~Hz}, 1 \mathrm{H}), 3.35-3.24(\mathrm{~m}, 2 \mathrm{H})$, 2.56 (ddd, $J=15.1,11.1,3.8 \mathrm{~Hz}, 1 \mathrm{H}), 1.83$ (dddd, $J=15.2,3.5,2.2$, $1.1 \mathrm{~Hz}, 1 \mathrm{H}) ;{ }^{13} \mathrm{C}\left\{{ }^{1} \mathrm{H}\right\}$ NMR (101 MHz, chloroform- $d$ ) $\delta 212.2$, $139.5,139.0,137.0,135.9,135.9,135.2,134.9,133.7,127.8,124.9$, $124.7,123.4,122.6,122.5,86.4,84.7,66.7,60.7,35.7,34.1$; FTIRATR $\nu_{\max } / \mathrm{cm}^{-1} 2035$ (Fe-CO), 1946 (Fe-CO); HRMS (ESI+) $\mathrm{m} /$ $z:[\mathrm{M}+\mathrm{H}]^{+}$calcd for $\mathrm{C}_{23} \mathrm{H}_{17} \mathrm{FeO}_{3} \mathrm{~S} 429.0248$; found 429.0246 .

Tricarbonyl[((3-(cyclohexa-2,4-dien-1-yl)azulen-1-yl)ethynyl)triisopropylsilane]iron (16). Synthesized according to general procedure $\mathrm{B}$ using azulene derivative $10(11.2 \mathrm{mg}, 0.0363$ mmol), iron complex $6(14.5 \mathrm{mg}, 0.0398 \mathrm{mmol})$, and $\mathrm{NaHCO}_{3}(6.1$ $\mathrm{mg}, 0.073 \mathrm{mmol})$ in $0.5 \mathrm{~mL}$ acetone. The product was purified by reversed-phase flash chromatography $\left(\mathrm{MeOH} / \mathrm{H}_{2} \mathrm{O} 70: 30 \rightarrow 100: 0\right)$, yielding 16 as a green sticky solid $(13.3 \mathrm{mg}, 70 \%) ;{ }^{1} \mathrm{H}$ NMR (400 $\mathrm{MHz}$, chloroform-d) $\delta 8.45(\mathrm{~d}, J=9.6 \mathrm{~Hz}, 1 \mathrm{H}), 8.15(\mathrm{~d}, J=9.6 \mathrm{~Hz}$, $1 \mathrm{H}), 7.81(\mathrm{~s}, 1 \mathrm{H}), 7.56($ app t, $J=9.8 \mathrm{~Hz}, 1 \mathrm{H}), 7.15($ app t, $J=9.9$ $\mathrm{Hz}, 1 \mathrm{H}), 7.12($ app t, $J=9.9 \mathrm{~Hz}, 1 \mathrm{H}), 5.61-5.57(\mathrm{~m}, 1 \mathrm{H}), 5.48(\mathrm{ddd}$, $J=6.0,4.1,1.5 \mathrm{~Hz}, 1 \mathrm{H}), 3.96(\mathrm{app} \mathrm{dt}, J=11.2,3.6 \mathrm{~Hz}, 1 \mathrm{H}), 3.27-$ $3.23(\mathrm{~m}, 2 \mathrm{H}), 2.51(\mathrm{ddd}, J=15.1,11.2,3.8 \mathrm{~Hz}, 1 \mathrm{H}), 1.79-1.72(\mathrm{~m}$, $1 \mathrm{H}), 1.21-1.19(\mathrm{~m}, 21 \mathrm{H}) ;{ }^{13} \mathrm{C}\left\{{ }^{1} \mathrm{H}\right\}$ NMR (101 MHz, chloroform-d) $\delta$ 212.2, 142.7, 139.0, 137.2, 136.5, 136.3, 135.1, 133.7, 123.8, 123.7, 110.1, 103.1, 95.2, 86.5, 84.8, 77.5, 77.2, 76.8, 66.4, 60.6, 35.6, 34.0, 19.0, 11.7; FTIR-ATR $\nu_{\max } / \mathrm{cm}^{-1} 2133(\mathrm{C} \equiv \mathrm{C}), 2039(\mathrm{Fe}-\mathrm{CO})$, $1954(\mathrm{Fe}-\mathrm{CO})$; HRMS (ESI+) $m / z:[\mathrm{M}+\mathrm{H}]^{+}$calcd for $\mathrm{C}_{30} \mathrm{H}_{35} \mathrm{FeO}_{3} \mathrm{Si}$ 527.1705; found 527.1727.

Tricarbonyl [3-(cyclohexa-2,4-dien-1-yl)azulene-1carbaldehyde]iron (17). Synthesized according to general procedure $B$ using azulene derivative $11(26.4 \mathrm{mg}, 0.169 \mathrm{mmol})$, iron complex $6(67.7 \mathrm{mg}, 0.186 \mathrm{mmol})$, and $\mathrm{NaHCO}_{3}(28.4 \mathrm{mg}, 0.338$ $\mathrm{mmol}$ ), with an extended reaction time of $16 \mathrm{~h}$. The product was purified by reversed-phase flash chromatography $\left(\mathrm{MeOH} / \mathrm{H}_{2} \mathrm{O}\right.$ 86:14), yielding 17 as a green solid (31.8 mg, 50\%); mp 131-134 ${ }^{\circ} \mathrm{C} ;{ }^{1} \mathrm{H}$ NMR (400 MHz, chloroform-d) $\delta 10.87$ (s (br), $1 \mathrm{H}$ ), 9.44 (d, $J=9.0 \mathrm{~Hz}, 1 \mathrm{H}), 8.39(\mathrm{~d}, J=9.7 \mathrm{~Hz}, 1 \mathrm{H}), 8.17(\mathrm{~s}, 1 \mathrm{H}), 7.83($ app t $J$ $=9.6 \mathrm{~Hz}, 1 \mathrm{H}), 7.58-7.42(\mathrm{~m}, 2 \mathrm{H}), 5.65-5.57(\mathrm{~m}, 1 \mathrm{H}), 5.55-5.47$ $(\mathrm{m}, 1 \mathrm{H}), 3.98($ app dt, $J=11.2,3.4 \mathrm{~Hz}, 1 \mathrm{H}), 3.30-3.23(\mathrm{~m}, 2 \mathrm{H})$, 2.56 (ddd, $J=15.1,11.2,3.7 \mathrm{~Hz}, 1 \mathrm{H}), 1.76(\mathrm{~d}, J=15.4 \mathrm{~Hz}, 1 \mathrm{H})$; ${ }^{13} \mathrm{C}\left\{{ }^{1} \mathrm{H}\right\}$ NMR (101 MHz, DMSO-d $\left.d_{6}\right) \delta 212.8,186.2,141.2,141.1$, 141.0, 137.8, 137.2, 136.9, 136.8, 129.6, 128.5, 124.4, 87.3, 85.4, 66.9, 61.9, 34.9, 34.0; FTIR-ATR $\nu_{\text {max }} / \mathrm{cm}^{-1} 2032$ (Fe-CO), $1944(\mathrm{Fe}-$ $\mathrm{CO}), 1638(\mathrm{C}=\mathrm{O})$; HRMS (ESI+) $m / z:[\mathrm{M}+\mathrm{H}]^{+}$calcd for $\mathrm{C}_{20} \mathrm{H}_{15} \mathrm{FeO}_{4}$ 375.0320; found 375.0320.

Hexacarbonyl[ 1,3-di (cyclohexa-2,4-dien-1-yl)-6phenylazulene]diiron $\left(18,18^{\prime}\right)$. Synthesized according to general procedure A using azulene $(21.0 \mathrm{mg}, 0.103 \mathrm{mmol})$, iron complex 6 $(82.3 \mathrm{mg}, 0.226 \mathrm{mmol})$, and $\mathrm{NaHCO}_{3}(34.5 \mathrm{mg}, 0.411 \mathrm{mmol})$. The product was purified by reversed-phase flash chromatography 
$\left(\mathrm{MeOH} / \mathrm{H}_{2} \mathrm{O} 95: 5\right)$, yielding an equimolar mixture of diastereomers 18 and $18^{\prime}$ as a green sticky solid (54.8 mg, 83\%); ${ }^{1} \mathrm{H}$ NMR (400 $\mathrm{MHz}$, chloroform- $d) \delta 8.14(\mathrm{~d}, J=9.5 \mathrm{~Hz}, 2 \mathrm{H}), 7.64-7.59(\mathrm{~m}, 2 \mathrm{H})$, $7.52-7.40(\mathrm{~m}, 4 \mathrm{H}), 7.19(\mathrm{~d}, J=10.2 \mathrm{~Hz}, 2 \mathrm{H}), 5.68-5.60(\mathrm{~m}, 2 \mathrm{H})$, $5.53-5.43(\mathrm{~m}, 2 \mathrm{H}), 4.01(\mathrm{app} \mathrm{dt} J=11.2,3.6 \mathrm{~Hz}, 2 \mathrm{H}), 3.35-3.24$ $(\mathrm{m}, 4 \mathrm{H}), 2.60-2.46(\mathrm{~m}, 2 \mathrm{H}), 1.86-1.75(\mathrm{~m}, 2 \mathrm{H}) ;{ }^{13} \mathrm{C}\left\{{ }^{1} \mathrm{H}\right\} \mathrm{NMR}$ (101 MHz, chloroform-d) $\delta 212.3,151.7,145.2,134.9,134.9,134.3$, 134.3, 132.4, 132.2, 132.1, 128.8, 128.4, 128.1, 122.0, 86.3, 86.2, 84.7, 84.7, 67.1, 67.1, 60.8, 60.8, 36.0, 36.0, 34.0, 33.9; FTIR-ATR $\nu_{\max } /$ $\mathrm{cm}^{-1} 2037$ (Fe-CO), 1942 (Fe-CO); HRMS (ESI+) $\mathrm{m} / z$ : [M + $\mathrm{H}]^{+}$calcd for $\mathrm{C}_{34} \mathrm{H}_{25} \mathrm{Fe}_{2} \mathrm{O}_{6}$ 641.0349; found 641.0340.

7-Isopropyl-1,4-dimethylazulen-2-amine (24). To a microwave reaction vial equipped with a magnetic stirring bar was added 2(7-isopropyl-1,4-dimethyl-azulen-2-yl)-4,4,5,5-tetramethyl-1,3,2-dioxaborolane 20 (111.7 mg, $0.344 \mathrm{mmol})$, hydroxylamine- $O$-sulfonic acid $(81.2 \mathrm{mg}, 0.718 \mathrm{mmol})$, acetonitrile $(2.0 \mathrm{~mL})$, and $1 \mathrm{M}$ aqueous $\mathrm{NaOH}(2.0 \mathrm{~mL})$. The vial was capped and stirred at room temperature for $24 \mathrm{~h}$. The reaction mixture was diluted with $2 \mathrm{~mL}$ water and extracted with EtOAc $(2 \times 10 \mathrm{~mL})$, and the organic phase was dried over $\mathrm{Na}_{2} \mathrm{SO}_{4}$ and concentrated under reduced pressure. The crude product was purified using flash column chromatography (petroleum ether/EtOAc, 100:0 $\rightarrow$ 95:5), yielding 24 as a yellowbrown viscous liquid (26.9 mg, 37\%). ${ }^{1} \mathrm{H}$ NMR (400 MHz, chloroform- $d$ ) $\delta 7.81(\mathrm{~d}, J=1.8 \mathrm{~Hz}, 1 \mathrm{H}), 7.12(\mathrm{dd}, J=10.6,1.8$ $\mathrm{Hz}, 1 \mathrm{H}), 6.99$ (d, $J=10.6 \mathrm{~Hz}, 1 \mathrm{H}), 6.59(\mathrm{~s}, 1 \mathrm{H}), 4.39(\mathrm{~s}, 2 \mathrm{H}), 3.05$ (hept, $J=6.9 \mathrm{~Hz}, 1 \mathrm{H}), 2.73(\mathrm{~s}, 3 \mathrm{H}), 2.39(\mathrm{~d}, J=0.6 \mathrm{~Hz}, 3 \mathrm{H}), 1.35(\mathrm{~d}$, $J=6.9 \mathrm{~Hz}, 6 \mathrm{H}) ;{ }^{13} \mathrm{C}\left\{{ }^{1} \mathrm{H}\right\}$ NMR (101 MHz, chloroform- $\left.d\right) \delta 153.4$, 141.5, 138.0, 137.3, 135.8, 128.3, 126.7, 126.3, 107.4, 99.7, 38.7, 25.0, 24.2, 8.9; FTIR-ATR $\nu_{\max } / \mathrm{cm}^{-1} 3471(\mathrm{~N}-\mathrm{H}), 3355(\mathrm{~N}-\mathrm{H}), 1617$ $(\mathrm{N}-\mathrm{H})$; HRMS (ESI+) $m / z:[\mathrm{M}+\mathrm{H}]^{+}$calcd for $\mathrm{C}_{15} \mathrm{H}_{20} \mathrm{~N}$ 214.1596; found 214.1605.

$\mathrm{N}$-(7-Isopropyl-1,4-dimethylazulen-2-yl)acetamide (25). To a microwave reaction vial equipped with a magnetic stirring bar was added 2-(7-isopropyl-1,4-dimethyl-azulen-2-yl)-4,4,5,5-tetramethyl1,3,2-dioxaborolane $20(213.0 \mathrm{mg}, 0.657 \mathrm{mmol})$, hydroxylamine- $O$ sulfonic acid $(223.0 \mathrm{mg}, 1.97 \mathrm{mmol})$, acetonitrile $(3.0 \mathrm{~mL})$, and $1 \mathrm{M}$ aqueous $\mathrm{NaOH}(4.0 \mathrm{~mL})$. The vial was capped and stirred at room temperature for $24 \mathrm{~h}$. The reaction mixture was diluted with water (5 $\mathrm{mL}$ ) and extracted with dichloromethane. The organic phase was dried over $\mathrm{Na}_{2} \mathrm{SO}_{4}$, and the solvent was evaporated under reduced pressure. The crude aminoazulene $\mathbf{2 4}$ was then redissolved in dichloromethane $(10.0 \mathrm{~mL})$. Acetic anhydride $(0.5 \mathrm{~mL})$ and pyridine $(0.5 \mathrm{~mL})$ were added, and the reaction was stirred at room temperature for $14 \mathrm{~h}$. The reaction mixture was reduced in vacuo, and the crude product was purified using flash column chromatography (20\% EtOAc in petroleum ether), yielding 25 as a blue crystalline solid $(60.0 \mathrm{mg}, 36 \%)$; mp $153-154{ }^{\circ} \mathrm{C}$; ${ }^{1} \mathrm{H}$ NMR (400 $\mathrm{MHz}$, chloroform- $d) \delta 8.07(\mathrm{~d}, J=1.9 \mathrm{~Hz}, 1 \mathrm{H}), 7.91(\mathrm{~s}, 1 \mathrm{H}), 7.66(\mathrm{~s}$ (br), 1H), $7.34(\mathrm{dd}, J=10.8,1.9 \mathrm{~Hz}, 1 \mathrm{H}), 7.09(\mathrm{~d}, J=10.7 \mathrm{~Hz}, 1 \mathrm{H})$, 3.09 (hept, $J=6.9 \mathrm{~Hz}, 1 \mathrm{H}), 2.84(\mathrm{~s}, 3 \mathrm{H}), 2.51(\mathrm{~s}, 3 \mathrm{H}), 2.32(\mathrm{~s}, 3 \mathrm{H})$, $1.37(\mathrm{~d}, J=6.9 \mathrm{~Hz}, 6 \mathrm{H}) ;{ }^{13} \mathrm{C}\left\{{ }^{1} \mathrm{H}\right\}$ NMR $\left(101 \mathrm{MHz}, \mathrm{DMSO}-d_{6}\right) \delta$ $168.6,143.9,140.4,140.1,136.2,134.6,131.5,129.9,126.1,111.3$, 104.7, 37.6, 24.7, 23.9, 23.7, 9.4; FTIR-ATR $\nu_{\max } / \mathrm{cm}^{-1} 3302(\mathrm{~N}-$ $\mathrm{H}), 1665(\mathrm{C}=\mathrm{O})$; HRMS (ESI $) \mathrm{m} / z:[\mathrm{M}+\mathrm{H}]^{+}$calcd for $\mathrm{C}_{17} \mathrm{H}_{22} \mathrm{NO} 256.1701$; found 256.1711 .

Tricarbonyl[3-(cyclohexa-2,4-dien-1-yl)-7-isopropyl-1,4dimethylazulene]iron (26). Synthesized according to general procedure A using guaiazulene $1(21.8 \mathrm{mg}, 0.110 \mathrm{mmol})$, iron complex 6 (36.4 mg, $0.100 \mathrm{mmol}$ ), and $\mathrm{NaHCO}_{3}(12.6 \mathrm{mg}, 0.150$ $\mathrm{mmol}$ ), with a reaction time of $16 \mathrm{~h}$. The product was purified by reversed-phase chromatography $\left(\mathrm{MeOH} / \mathrm{H}_{2} \mathrm{O}, 60: 40 \rightarrow 85: 15\right)$, yielding 26 as a blue sticky solid ( $41.6 \mathrm{mg}, 98 \%$ ); this product was also synthesized on a $1 \mathrm{mmol}$ scale, yielding $392 \mathrm{mg}$ of $26(94 \%) ;{ }^{1} \mathrm{H}$ NMR (400 MHz, chloroform- $d) \delta 8.00(\mathrm{~d}, J=2.1 \mathrm{~Hz}, 1 \mathrm{H}), 7.53(\mathrm{~s}$, $1 \mathrm{H}), 7.21$ (dd, $J=10.6,2.2 \mathrm{~Hz}, 1 \mathrm{H}), 6.79(\mathrm{~d}, J=10.6 \mathrm{~Hz}, 1 \mathrm{H}), 5.63-$ $5.57(\mathrm{~m}, 1 \mathrm{H}), 5.49$ (ddd, $J=5.9,4.1,1.5 \mathrm{~Hz}, 1 \mathrm{H}), 4.39($ app dt, $J=$ 11.0, 3.7 Hz, 1H), 3.30-3.22 (m, $2 \mathrm{H}), 2.99$ (hept, $J=6.9 \mathrm{~Hz}, 1 \mathrm{H})$, $2.90(\mathrm{~s}, 3 \mathrm{H}), 2.59(\mathrm{~d}, J=0.7 \mathrm{~Hz}, 3 \mathrm{H}), 2.42(\mathrm{ddd}, J=15.2,11.0,4.0$ $\mathrm{Hz}, 1 \mathrm{H}), 1.73$ (dddd, $J=15.2,3.7,2.2,1.1 \mathrm{~Hz}, 1 \mathrm{H}), 1.31(\mathrm{~d}, J=6.9$ $\mathrm{Hz}, 6 \mathrm{H}) ;{ }^{13} \mathrm{C}\left\{{ }^{1} \mathrm{H}\right\}$ NMR (101 MHz, chloroform-d) $\delta 212.3,144.5$,
$139.5,138.4,136.7,134.4,133.5,132.8,130.9,126.5,124.8,85.8$, $84.8,68.5,60.5,38.1,37.6,35.0,27.3,24.5,13.1$; FTIR-ATR $\nu_{\max } /$ $\mathrm{cm}^{-1} 2040$ (Fe-CO), 1957 (Fe-CO); HRMS (ESI+) $\mathrm{m} / z:[\mathrm{M}+$ $\mathrm{H}]^{+}$calcd for $\mathrm{C}_{24} \mathrm{H}_{25} \mathrm{FeO}_{3}$ 417.1153; found 417.1155.

Tricarbonyl[7-isopropyl-3-(4-methoxycyclohexa-2,4-dien-1yl)-1,4-dimethylazulene]iron (27). Synthesized according to general procedure A using guaiazulene $1(21.8 \mathrm{mg}, 0.110 \mathrm{mmol})$, iron complex $7(39.4 \mathrm{mg}, 0.100 \mathrm{mmol})$, and $\mathrm{NaHCO}_{3}(12.6 \mathrm{mg}$, $0.150 \mathrm{mmol}$ ), with a reaction time of $16 \mathrm{~h}$. The product was purified by reversed-phase chromatography $\left(\mathrm{MeOH} / \mathrm{H}_{2} \mathrm{O}, 60: 40 \rightarrow 85: 15\right)$, yielding 27 as a blue solid (41.4 mg, 93\%); mp 101-103 ${ }^{\circ} \mathrm{C} ;{ }^{1} \mathrm{H}$ NMR (400 MHz, chloroform-d) $\delta 8.01(\mathrm{~d}, J=2.2 \mathrm{~Hz}, 1 \mathrm{H}), 7.49$ (s, $1 \mathrm{H}), 7.22(\mathrm{dd}, J=10.6,2.2 \mathrm{~Hz}, 1 \mathrm{H}), 6.79(\mathrm{~d}, J=10.7 \mathrm{~Hz}, 1 \mathrm{H}), 5.26$ (dd, $J=6.6,2.4 \mathrm{~Hz}, 1 \mathrm{H}), 4.22(\mathrm{app} \mathrm{dt}, J=11.0,3.6 \mathrm{~Hz}, 1 \mathrm{H}), 3.74(\mathrm{~s}$, $3 \mathrm{H}), 3.50$ (app dt, $J=3.9,2.3 \mathrm{~Hz}, 1 \mathrm{H}), 2.99$ (hept, $J=6.9 \mathrm{~Hz}, 1 \mathrm{H}$ ), $2.90(\mathrm{~s}, 3 \mathrm{H}), 2.85(\mathrm{dd}, J=6.6,3.4 \mathrm{~Hz}, 1 \mathrm{H}), 2.60(\mathrm{~s}, 3 \mathrm{H}), 2.44(\mathrm{ddd}, J$ $=14.8,10.9,3.9 \mathrm{~Hz}, 1 \mathrm{H}), 1.85(\mathrm{ddd}, J=14.7,3.7,2.3 \mathrm{~Hz}, 1 \mathrm{H}), 1.32$ $(\mathrm{d}, J=6.9 \mathrm{~Hz}, 6 \mathrm{H}) ;{ }^{13} \mathrm{C}\left\{{ }^{1} \mathrm{H}\right\} \mathrm{NMR}(101 \mathrm{MHz}$, chloroform-d $) \delta 211.7$ (br), 144.7, 140.3, 139.6, 138.5, 136.6, 134.6, 133.7, 133.0, 131.1, 126.7, 124.9, 67.2, 57.5, 54.6, 53.6, 38.0, 37.7, 36.2, 27.5, 24.7, 13.2; FTIR-ATR $\nu_{\max } / \mathrm{cm}^{-1} 2036$ (Fe-CO), 1958 (Fe-CO); HRMS (ESI +) $\mathrm{m} / z:[\mathrm{M}+\mathrm{H}]^{+}$calcd for $\mathrm{C}_{25} \mathrm{H}_{27} \mathrm{FeO}_{4}$ 447.1258; found 447.1258.

Tricarbonyl[methyl 5-(3-formyl-5-isopropyl-8-methylazulen-1-yl)cyclohexa-1,3-diene-1-carboxylate]iron (28). Synthesized according to general procedure A using azulene derivative 19 $(23.4 \mathrm{mg}, 0.110 \mathrm{mmol})$, iron complex $2(42.2 \mathrm{mg}, 0.100 \mathrm{mmol})$, and $\mathrm{NaHCO}_{3}(12.6 \mathrm{mg}, 0.150 \mathrm{mmol})$, with a reaction time of $16 \mathrm{~h}$. The product was purified by reversed-phase chromatography $(\mathrm{MeOH} /$ $\mathrm{H}_{2} \mathrm{O} 60: 40 \rightarrow 85: 15$ ), yielding 28 as a purple solid (27.3 mg, 56\%); $\mathrm{mp} 74-76^{\circ} \mathrm{C} ;{ }^{1} \mathrm{H}$ NMR (400 MHz, chloroform- $\left.d\right) \delta 10.27(\mathrm{~s}, 1 \mathrm{H})$, $9.60(\mathrm{~s}, 1 \mathrm{H}), 8.10(\mathrm{~s}, 1 \mathrm{H}), 7.57(\mathrm{dd}, J=10.8,2.2 \mathrm{~Hz}, 1 \mathrm{H}), 7.35(\mathrm{~d}, J=$ $10.7 \mathrm{~Hz}, 1 \mathrm{H}), 6.33(\mathrm{~d}, J=4.3 \mathrm{~Hz}, 1 \mathrm{H}), 5.66(\mathrm{dd}, J=6.3,4.4 \mathrm{~Hz}, 1 \mathrm{H})$, 4.48 (app dt, $J=11.4,4.0 \mathrm{~Hz}, 1 \mathrm{H}), 3.72(\mathrm{~s}, 3 \mathrm{H}), 3.44(\mathrm{ddd}, J=6.4$, $3.2,1.4 \mathrm{~Hz}, 1 \mathrm{H}), 3.15$ (hept, $J=6.9 \mathrm{~Hz}, 1 \mathrm{H}), 3.07(\mathrm{~s}, 3 \mathrm{H}), 2.91$ (dd, $J$ $=15.1,11.3 \mathrm{~Hz}, 1 \mathrm{H}), 1.54(\mathrm{dd}, J=15.1,4.4 \mathrm{~Hz}, 1 \mathrm{H}), 1.37(\mathrm{~d}, J=6.9$ $\mathrm{Hz}, 6 \mathrm{H}) ;{ }^{13} \mathrm{C}\left\{{ }^{1} \mathrm{H}\right\}$ NMR (101 MHz, chloroform-d) $\delta$ 185.9, 172.3, $149.0,148.0,141.6,141.3,139.4,137.3,137.2,135.3,133.0,124.1$, 89.1, 84.8, 67.7, 62.4, 51.7, 39.3, 37.9, 33.8, 27.5, 24.4. Signal for $\mathrm{Fe}-$ $\mathrm{CO}$ not seen; FTIR-ATR $\nu_{\max } / \mathrm{cm}^{-1} 2050(\mathrm{Fe}-\mathrm{CO}), 1974(\mathrm{Fe}-\mathrm{CO})$, $1707(\mathrm{C}=\mathrm{O}), 1643(\mathrm{C}=\mathrm{O})$; HRMS (ESI+) $m / z:[\mathrm{M}+\mathrm{H}]^{+}$calcd for $\mathrm{C}_{26} \mathrm{H}_{25} \mathrm{FeO}_{6}$ 489.1000; found 489.1016 .

Tricarbonyl[methyl 5-(5-isopropyl-3,8-dimethyl-2-(4,4,5,5tetramethyl-1,3,2-dioxaborolan-2-yl)azulen-1-yl)cyclohexa1,3-diene-1-carboxylate]iron (29). Synthesized according to general procedure A using azulene derivative $20(35.7 \mathrm{mg}, 0.110$ mmol), iron complex $2(42.2 \mathrm{mg}, 0.100 \mathrm{mmol})$, and $\mathrm{NaHCO}_{3}(12.6$ $\mathrm{mg}, 0.150 \mathrm{mmol}$ ), with a reaction time of $16 \mathrm{~h}$. The product was purified by reversed-phase chromatography $\left(\mathrm{MeOH} / \mathrm{H}_{2} \mathrm{O}\right.$ 60:40 $\rightarrow$ 90:10), yielding 29 as a green oil $(26.5 \mathrm{mg}, 43 \%) ;{ }^{1} \mathrm{H}$ NMR (400 $\mathrm{MHz}$, chloroform- $d$ ) $\delta 8.01(\mathrm{~d}, J=2.0 \mathrm{~Hz}, 1 \mathrm{H}), 7.20(\mathrm{dd}, J=10.6,2.1$ $\mathrm{Hz}, 1 \mathrm{H}), 6.83(\mathrm{~d}, J=10.6 \mathrm{~Hz}, 1 \mathrm{H}), 6.30(\mathrm{~d}, J=4.3 \mathrm{~Hz}, 1 \mathrm{H}), 5.39$ (dd, $J=6.5,4.3 \mathrm{~Hz}, 1 \mathrm{H}), 4.82(\mathrm{ddd}, J=11.0,5.7,2.6 \mathrm{~Hz}, 1 \mathrm{H}), 3.73$ (s, $3 \mathrm{H}), 3.37$ (ddd, $J=6.4,2.6,1.2 \mathrm{~Hz}, 1 \mathrm{H}), 3.00$ (s, 3H), 2.97 (hept, $J=6.9 \mathrm{~Hz}, 1 \mathrm{H}), 2.76(\mathrm{dd}, J=15.0,11.1 \mathrm{~Hz}, 1 \mathrm{H}), 2.64(\mathrm{~s}, 3 \mathrm{H}), 1.88$ $(\mathrm{dd}, J=15.0,5.8 \mathrm{~Hz}, 1 \mathrm{H}), 1.48(\mathrm{~s}, 6 \mathrm{H}), 1.44(\mathrm{~s}, 6 \mathrm{H}), 1.31(\mathrm{~d}, J=6.9$ $\mathrm{Hz}, 6 \mathrm{H}) ;{ }^{13} \mathrm{C}\left\{{ }^{1} \mathrm{H}\right\}$ NMR (101 MHz, chloroform-d) $\delta 210.8$ (br), $173.0,144.6,140.0,139.3,135.0,134.8,133.6,133.2,131.2,127.6$, $87.9,85.6,84.0,71.4,62.9,51.7,41.4,37.6,29.83,28.55,25.90,25.48$, 24.58, 13.12. Signal for $C$-B not seen; FTIR-ATR $\nu_{\max } / \mathrm{cm}^{-1} 2045$ (Fe-CO), 1968 (Fe-CO), 1708 (CO); HRMS (ESI+) m/z: [M + $\mathrm{H}]^{+}$calcd for $\mathrm{C}_{32} \mathrm{H}_{38} \mathrm{BFeO}_{7}$ 601.2059; found 601.2049.

Tricarbonyl[methyl 5-(2-iodo-5-isopropyl-3,8-dimethylazulen-1-yl)cyclohexa-1,3-diene-1-carboxylate]iron (30). Synthesized according to general procedure A using azulene derivative 21 $(28.6 \mathrm{mg}, 0.088 \mathrm{mmol})$, iron complex $2(40.9 \mathrm{mg}, 0.097 \mathrm{mmol})$, and $\mathrm{NaHCO}_{3}(11.1 \mathrm{mg}, 0.132 \mathrm{mmol})$, with a reaction time of $16 \mathrm{~h}$. The product was purified by reversed-phase chromatography $(\mathrm{MeOH} /$ $\left.\mathrm{H}_{2} \mathrm{O}, 60: 40 \rightarrow 90: 10\right)$, yielding 30 as a blue oil (33.4 mg, 63\%); although stable in neat form, the product was found to be somewhat unstable in chloroform- $d$ solution. Increased stability was observed 
when the $\mathrm{CDCl}_{3}$ was filtered through a plug of basic aluminum oxide prior to use; ${ }^{1} \mathrm{H}$ NMR (400 MHz, chloroform- $d$ ) $\delta 8.13$ (d, $J=2.1$ $\mathrm{Hz}, 1 \mathrm{H}), 7.34(\mathrm{dd}, J=10.7,2.1 \mathrm{~Hz}, 1 \mathrm{H}), 6.98(\mathrm{~d}, J=10.7 \mathrm{~Hz}, 1 \mathrm{H})$, $6.33(\mathrm{~d}, J=4.3 \mathrm{~Hz}, 1 \mathrm{H}), 5.66(\mathrm{dd}, J=6.5,4.3 \mathrm{~Hz}, 1 \mathrm{H}), 4.97(\mathrm{ddd}, J=$ 11.0, 6.4, $2.5 \mathrm{~Hz}, 1 \mathrm{H}), 3.74(\mathrm{~s}, 3 \mathrm{H}), 3.13$ (d, $J=5.6 \mathrm{~Hz}, 1 \mathrm{H}), 3.09-$ $2.97(\mathrm{~m}, 4 \mathrm{H}), 2.65(\mathrm{dd}, J=14.8,11.2 \mathrm{~Hz}, 1 \mathrm{H}), 2.59(\mathrm{~s}, 3 \mathrm{H}), 1.97$ (dd, $J=14.8,6.3 \mathrm{~Hz}, 1 \mathrm{H}), 1.33(\mathrm{~d}, J=6.9 \mathrm{~Hz}, 6 \mathrm{H}) ;{ }^{13} \mathrm{C}\left\{{ }^{1} \mathrm{H}\right\} \mathrm{NMR}$ (101 MHz, chloroform-d) $\delta 210.9$ (br), 173.0, 143.3, 141.8, 136.2, $134.9,133.8,133.2,129.0,128.8,126.4,105.7,88.9,86.4,67.5,63.2$, $51.8,40.5,37.7,29.0,26.8,24.7,16.3$; FTIR-ATR $\nu_{\max } / \mathrm{cm}^{-1} 2048$ (Fe-CO), $1972(\mathrm{Fe}-\mathrm{CO}), 1706(\mathrm{C}=\mathrm{O})$; HRMS (ESI+) $\mathrm{m} / z$ : $[\mathrm{M}+$ $\mathrm{H}]^{+}$calcd for $\mathrm{C}_{26} \mathrm{H}_{26} \mathrm{FeIO}_{5} 601.0174$; found 601.0177 .

Tricarbonyl[methyl 5-(2-bromo-5-isopropyl-3,8-dimethylazulen-1-yl)cyclohexa-1,3-diene-1-carboxylate]iron (31). Synthesized according to general procedure A using azulene derivative 22 (10.0 mg, 0.0361) mmol, iron complex 2 (13.9 mg, 0.0329), and $\mathrm{NaHCO}_{3}(5.5 \mathrm{mg}, 0.066 \mathrm{mmol})$ in $0.5 \mathrm{~mL}$ acetone, with a reaction time of $4 \mathrm{~h}$. The product was purified by reversed-phase chromatography $\left(\mathrm{MeOH} / \mathrm{H}_{2} \mathrm{O} 60: 40 \rightarrow 90: 10\right)$, yielding 31 as a blue solid (14.4 mg, 79\%). Although stable in neat form, the product was found to be somewhat unstable in chloroform-d solution. Increased stability was observed when the $\mathrm{CDCl}_{3}$ was filtered through a plug of basic aluminum oxide prior to use; mp $147-149{ }^{\circ} \mathrm{C} ;{ }^{1} \mathrm{H}$ NMR (400 MHz, chloroform- $d) \delta 8.10(\mathrm{~d}, J=2.2 \mathrm{~Hz}, 1 \mathrm{H}), 7.33$ (dd, $J=10.7,2.1 \mathrm{~Hz}, 1 \mathrm{H}), 6.99(\mathrm{~d}, J=10.7 \mathrm{~Hz}, 1 \mathrm{H}), 6.30(\mathrm{dd}, J=4.3,1.1$ $\mathrm{Hz}, 1 \mathrm{H}), 5.61(\mathrm{dd}, J=6.4,4.4 \mathrm{~Hz}, 1 \mathrm{H}), 4.90(\mathrm{ddd}, J=10.9,5.9,2.6$ $\mathrm{Hz}, 1 \mathrm{H}$ ), 3.73 (s, 3H), 3.15 (ddd, $J=6.5,2.7,1.3 \mathrm{~Hz}, 1 \mathrm{H}), 3.09-2.97$ $(\mathrm{m}, 4 \mathrm{H}), 2.65(\mathrm{dd}, J=14.7,11.3 \mathrm{~Hz}, 1 \mathrm{H}), 2.55(\mathrm{~s}, 3 \mathrm{H}), 1.93$ (ddd, $J$ $=14.8,6.0,0.9 \mathrm{~Hz}, 1 \mathrm{H}), 1.33(\mathrm{~d}, J=6.9 \mathrm{~Hz}, 6 \mathrm{H}) ;{ }^{13} \mathrm{C}\left\{{ }^{1} \mathrm{H}\right\} \mathrm{NMR}$ $\left(101 \mathrm{MHz}\right.$, methylene chloride- $\left.d_{2}\right) \delta 173.1,144.3,142.3,136.5$, 135.1, 133.4, 133.2, 129.6, 129.4, 125.1, 124.7, 88.2, 87.2, 67.6, 63.8, 51.9, 40.0, 38.1, 29.0, 27.6, 24.8, 12.7. Signal for $\mathrm{Fe}-\mathrm{CO}$ not seen; FTIR-ATR $\nu_{\max } / \mathrm{cm}^{-1} 2047$ (Fe-CO), 1968 (Fe-CO), 1705 (C= $\mathrm{O})$; HRMS (ESI+) $m / z:[\mathrm{M}+\mathrm{H}]^{+}$calcd for $\mathrm{C}_{26} \mathrm{H}_{26} \mathrm{BrFeO}_{5}$ 553.0313; found 553.0324.

General Procedure for the Photocatalytic Decomplexation, Exemplified by the Formation of 1-(Cyclohexa-2,4-dien-1-yl)-3phenylazulene (33). To a $100 \mathrm{~mL}$ borosilicate glass round-bottom flask equipped with a magnetic stirring bar, $25.0 \mathrm{mg}(0.0592 \mathrm{mmol})$ of 13 was added and dissolved in $24 \mathrm{~mL}$ of acetonitrile. The flask was sealed with a rubber septum, which was pierced with a syringe needle open to the atmosphere. The flask was placed $5 \mathrm{~cm}$ from a low-energy black light lamp (Velleman lighting, $15 \mathrm{~W}, 850 \mathrm{~lm}$ ) in a container lined with aluminum foil. The reaction mixture was irradiated (emission maximum of $370 \mathrm{~nm}$; for emission spectrum, see Figure S71) without the use of any filter under stirring in room temperature, cooled by a stream of air, for $72 \mathrm{~h}$. The solvent was removed under reduced pressure, and the residue was redissolved in dichloromethane, filtered through a plug of silica, and the solvent was evaporated under a stream of nitrogen. The crude product was purified by reversedphase flash chromatography (methanol/water, 84:16), yielding 33 as a green sticky solid (13.1 mg, 78\%); ${ }^{1} \mathrm{H}$ NMR $(400 \mathrm{MHz}$, chloroformd) $\delta 8.49(\mathrm{~d}, J=9.8 \mathrm{~Hz}, 1 \mathrm{H}), 8.36(\mathrm{~d}, J=9.7 \mathrm{~Hz}, 1 \mathrm{H}), 8.04(\mathrm{~s}, 1 \mathrm{H})$, 7.64-7.61 (m, 2H), 7.57-7.45 (m, 3H), 7.40-7.32 (m, 1H), 7.14$7.02(\mathrm{~m}, 2 \mathrm{H}), 6.16-6.04(\mathrm{~m}, 2 \mathrm{H}), 6.04-5.99(\mathrm{~m}, 1 \mathrm{H}), 5.94-5.88$ $(\mathrm{m}, 1 \mathrm{H}), 4.34$ (app ddt, $J=12.5,9.2,3.0 \mathrm{~Hz}, 1 \mathrm{H}), 2.68$ (dddd, $J=$ $17.3,9.2,4.9,1.3 \mathrm{~Hz}, 1 \mathrm{H}$ ), 2.57 (dddd, $J=17.2,13.3,3.8,2.3 \mathrm{~Hz}$, $1 \mathrm{H}) ;{ }^{13} \mathrm{C}\left\{{ }^{1} \mathrm{H}\right\}$ NMR (101 MHz, chloroform- $\left.d\right) \delta 138.4,137.6,136.8$, 136.6, 136.0, 135.6, 133.7, 132.9, 131.1, 130.1, 129.9, 128.7, 126.4, 126.2, 124.3, 124.2, 123.0, 122.0, 32.1, 31.6; HRMS (ESI+) $m / z:[\mathrm{M}$ $+\mathrm{H}]^{+}$calcd for $\mathrm{C}_{22} \mathrm{H}_{19}$ 283.1486; found 283.1483.

4-(3-Phenylazulen-1-yl)cyclohex-2-en-1-one (34). Synthesized according to the general procedure, using $25.0 \mathrm{mg}(0.0553$ $\mathrm{mmol}$ ) of compound $\mathbf{1 4}$ dissolved in $25 \mathrm{~mL}$ of acetonitrile. The crude product was purified by flash chromatography (petroleum ether/ EtOAc 93:7), yielding 34 as a green sticky solid $(12.2 \mathrm{mg}, 74 \%) ;{ }^{1} \mathrm{H}$ NMR (400 MHz, chloroform- $d) \delta 8.53(\mathrm{~d}, J=10.0 \mathrm{~Hz}, 1 \mathrm{H}), 8.36(\mathrm{~d}$, $J=9.4 \mathrm{~Hz}, 1 \mathrm{H}), 7.87(\mathrm{~s}, 1 \mathrm{H}), 7.65-7.56(\mathrm{~m}, 3 \mathrm{H}), 7.52-7.46(\mathrm{~m}$, $2 \mathrm{H}), 7.38-7.33(\mathrm{~m}, 1 \mathrm{H}), 7.19-7.11(\mathrm{~m}, 3 \mathrm{H}), 6.23(\mathrm{ddd}, J=10.1$, $2.5,0.6 \mathrm{~Hz}, 1 \mathrm{H}), 4.46(\mathrm{ddt}, J=8.3,5.3,2.8 \mathrm{~Hz}, 1 \mathrm{H}), 2.69-2.47(\mathrm{~m}$,
$3 \mathrm{H}), 2.36-2.25(\mathrm{~m}, 1 \mathrm{H}) ;{ }^{13} \mathrm{C}\left\{{ }^{1} \mathrm{H}\right\}$ NMR (101 MHz, chloroform- $\left.d\right) \delta$ $199.7,153.9,138.9,137.1,136.7,136.3,136.2,136.1,133.7,130.3$, $129.9,129.6,129.4,128.8,126.7,123.6,122.5,37.3,35.2$, 31.9; FTIRATR $\nu_{\max } / \mathrm{cm}^{-1} 1674(\mathrm{C}=\mathrm{O})$; HRMS (ESI+) $\mathrm{m} / z:[\mathrm{M}+\mathrm{H}]^{+} \mathrm{calcd}$ for $\mathrm{C}_{22} \mathrm{H}_{19} \mathrm{O}$ 299.1436; found 299.1440 .

4-(5-Isopropyl-3,8-dimethylazulen-1-yl)cyclohex-2-en-1one (35). Synthesized according to the general procedure, using 41.4 $\mathrm{mg}(0.0928 \mathrm{mmol})$ of compound 27 , dissolved in $42 \mathrm{~mL}$ of acetonitrile in a $500 \mathrm{~mL}$ round-bottom flask. The crude product was purified by flash chromatography (petroleum ether/EtOAc 93:7), yielding 35 as a blue sticky oil (11.4 mg, $42 \%) ;{ }^{1} \mathrm{H}$ NMR $(400 \mathrm{MHz}$, chloroform- $d$ ) $\delta 8.13(\mathrm{~d}, J=2.2 \mathrm{~Hz}, 1 \mathrm{H}), 7.47(\mathrm{~s}, 1 \mathrm{H}), 7.33(\mathrm{dd}, J=$ 10.7, $2.2 \mathrm{~Hz}, 1 \mathrm{H}), 7.10$ (ddd, $J=10.1,3.0,1.2 \mathrm{~Hz}, 1 \mathrm{H}), 6.92$ (d, $J=$ $10.7 \mathrm{~Hz}, 1 \mathrm{H}), 6.16(\mathrm{dd}, J=10.1,2.5 \mathrm{~Hz}, 1 \mathrm{H}), 4.76$ (app ddt, $J=7.9$, $5.0,2.8 \mathrm{~Hz}, 1 \mathrm{H}), 3.05$ (hept, $J=6.9,1 \mathrm{H}) 3.02(\mathrm{~s}, 3 \mathrm{H}), 2.65-2.57(\mathrm{~m}$, $4 \mathrm{H}), 2.55-2.44(\mathrm{~m}, 2 \mathrm{H}), 2.23-2.11(\mathrm{~m}, 1 \mathrm{H}), 1.35(\mathrm{~d}, J=6.9 \mathrm{~Hz}$, $6 \mathrm{H}) ;{ }^{13} \mathrm{C}\left\{{ }^{1} \mathrm{H}\right\}$ NMR (101 MHz, chloroform-d) $\delta 199.9,155.4,144.7$, $140.1,138.1,137.8,135.2,134.1,131.6,128.8,128.0,127.3,125.0$, 37.8, 37.4, 37.0, 33.9, 27.5, 24.7, 13.1; FTIR-ATR $\nu_{\max } / \mathrm{cm}^{-1} 1679$ $\left(\mathrm{C}=\mathrm{O}\right.$ ); HRMS (ESI+) $m / z:[\mathrm{M}+\mathrm{H}]^{+}$calcd for $\mathrm{C}_{21} \mathrm{H}_{25} \mathrm{O} 293.1905$; found 293.1904.

1,3-Diphenylazulene (36). ${ }^{16 \mathrm{~b}}$ To a $5 \mathrm{~mL}$ microwave vial equipped with a stir bar, containing $27.4 \mathrm{mg}(0.0970 \mathrm{mmol})$ of compound 33, was added $24.2 \mathrm{mg}(0.107 \mathrm{mmol}) \mathrm{DDQ}$. The vial was put under an atmosphere of nitrogen. Toluene $(1.0 \mathrm{~mL})$ was added, and the solution was stirred at room temperature for $40 \mathrm{~min}$. The reaction mixture was diluted with ethyl acetate $(20 \mathrm{~mL})$ and washed with $1 \mathrm{M}$ aqueous $\mathrm{NaOH}(3 \times 20 \mathrm{~mL})$ followed by brine $(1 \times 20$ $\mathrm{mL}$ ). The organic phase was dried over $\mathrm{Na}_{2} \mathrm{SO}_{4}$, filtered, and concentrated under reduced pressure. The product was purified by flash chromatography (petroleum ether/EtOAc 99:1), yielding 36 as a blue-green solid (22.3 mg, 82\%); ${ }^{1} \mathrm{H}$ NMR (400 MHz, chloroform- $d$ ) $\delta 8.57(\mathrm{dd}, J=9.8,1.2 \mathrm{~Hz}, 2 \mathrm{H}), 8.15(\mathrm{~s}, 1 \mathrm{H}), 7.69-7.66(\mathrm{~m}, 4 \mathrm{H})$, $7.60(\mathrm{t}, J=9.8,1.2 \mathrm{~Hz}, 1 \mathrm{H}), 7.56-7.50(\mathrm{~m}, 4 \mathrm{H}), 7.40$ (app ddt, $J=$ $7.9,6.9,1.3 \mathrm{~Hz}, 2 \mathrm{H}), 7.14(\mathrm{dd}, J=9.8,9,8 \mathrm{~Hz}, 2 \mathrm{H}) ;{ }^{13} \mathrm{C}\left\{{ }^{1} \mathrm{H}\right\} \mathrm{NMR}$ $(101 \mathrm{MHz}$, chloroform- $d) \delta 139.1,137.4,137.3,136.8,136.3,130.7$, $130.0,128.8,126.6,123.6$. Analysis data are in accordance with published data for this compound. ${ }^{16 \mathrm{~b}}$

(7aS, 1 1 a R)-4-Isopropyl-2-methyl-7,7a,8, 10,11,11a-hexahydro-9H-naphtho[1,2,3-cd]azulen-9-one (37). In a $2 \mathrm{~mL}$ microwave vial equipped with a stir bar, compound $35(9.3 \mathrm{mg}, 0.032$ $\mathrm{mmol})$ was dissolved in THF $(1 \mathrm{~mL})$. The vial was capped and cooled in an ice bath. $t$-BuOK was added as a $1 \mathrm{M}$ solution in THF $(100 \mu \mathrm{L}$, $0.100 \mathrm{mmol})$. The solution was left to stir at $0{ }^{\circ} \mathrm{C}$ for $20 \mathrm{~min}$, after which it was poured into $1 \mathrm{M}$ aqueous $\mathrm{HCl}(10 \mathrm{~mL})$ and extracted with EtOAc $(3 \times 10 \mathrm{~mL})$. The combined organic extracts were dried over $\mathrm{Na}_{2} \mathrm{SO}_{4}$, filtered, and the solvent was removed under a stream of nitrogen. The product was purified by flash chromatography (petroleum ether/EtOAc 90:10), yielding 37 as a blue sticky oil (3.6 mg, 39\%); ${ }^{1} \mathrm{H}$ NMR (400 MHz, chloroform- $d$ ) $\delta 8.09$ (d, $J=1.8$ $\mathrm{Hz}, 1 \mathrm{H}), 7.54(\mathrm{~s}, 1 \mathrm{H}), 7.36(\mathrm{dd}, J=10.5,1.8 \mathrm{~Hz}, 1 \mathrm{H}), 6.77(\mathrm{~d}, J=$ $10.5 \mathrm{~Hz}, 1 \mathrm{H}), 3.61$ (app dt, $J=5.7,4.5 \mathrm{~Hz}, 1 \mathrm{H}), 3.25$ (dd, $J=16.8$, $4.4 \mathrm{~Hz}, 1 \mathrm{H}), 3.04$ (hept, $J=6.9 \mathrm{~Hz}, 1 \mathrm{H}), 2.91(\mathrm{dd}, J=16.8,6.6 \mathrm{~Hz}$, $1 \mathrm{H}), 2.84-2.75(\mathrm{~m}, 1 \mathrm{H}), 2.67(\mathrm{~s}, 3 \mathrm{H}), 2.49-2.42(\mathrm{~m}, 2 \mathrm{H}), 2.41-$ $2.36(\mathrm{~m}, 2 \mathrm{H}), 2.32(\mathrm{dd}, J=14.3,8.6 \mathrm{~Hz}, 1 \mathrm{H}), 2.25-2.18(\mathrm{~m}, 1 \mathrm{H})$, $1.35(\mathrm{~d}, J=6.9 \mathrm{~Hz}, 6 \mathrm{H}) ;{ }^{13} \mathrm{C}\left\{{ }^{1} \mathrm{H}\right\}$ NMR $(101 \mathrm{MHz}$, chloroform- $d) \delta$ 212.3, 144.0, 139.3, 135.8, 134.2, 133.4, 133.3, 133.0, 125.8, 124.5, 122.7, 44.6, 38.7, 38.7, 38.3, 37.7, 34.7, 30.4, 24.90, 24.91, 12.9; FTIRATR $\nu \max / \mathrm{cm}^{-1} 1709(\mathrm{C}=\mathrm{O})$; HRMS (ESI+) $\mathrm{m} / z:[\mathrm{M}+\mathrm{H}]^{+}$calcd for $\mathrm{C}_{21} \mathrm{H}_{25} \mathrm{O}$ 293.1905; found 293.1904.

\section{ASSOCIATED CONTENT}

\section{Supporting Information}

The Supporting Information is available free of charge at https://pubs.acs.org/doi/10.1021/acs.joc.0c01412.

Spectroscopic data for all products; NMR assignments and stereochemical elucidation of 37 ; colorimetric response to TFA and UV-vis/fluorescence spectra for 
selected compounds; and emission spectrum of lamp used for photolytic decomplexations (PDF)

\section{AUTHOR INFORMATION}

\section{Corresponding Authors}

Simon E. Lewis - Centre for Sustainable Circular Technologies and Department of Chemistry, University of Bath, Bath BA2

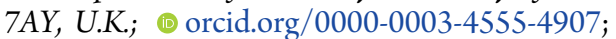

Email: S.E.Lewis@bath.ac.uk

Nina Kann - Department of Chemistry and Chemical Engineering, Chalmers University of Technology, SE-41296 Gothenburg, Sweden; 이이이.org/0000-0002-4457-5282; Email: kann@chalmers.se

\section{Authors}

Petter Dunås - Department of Chemistry and Chemical Engineering, Chalmers University of Technology, SE-41296 Gothenburg, Sweden; 이이이.org/0000-0002-3779-3265

Lloyd C. Murfin - Department of Chemistry, University of Bath, Bath BA2 7AY, U.K.; 10 orcid.org/0000-0003-47809539

Oscar J. Nilsson - Department of Chemistry and Chemical Engineering, Chalmers University of Technology, SE-41296 Gothenburg, Sweden; @ orcid.org/0000-0003-2716-2563

Nicolas Jame - Department of Chemistry and Chemical Engineering, Chalmers University of Technology, SE-41296 Gothenburg, Sweden; 이 orcid.org/0000-0002-0550-5134

Complete contact information is available at: https://pubs.acs.org/10.1021/acs.joc.0c01412

\section{Author Contributions}

All authors have given approval to the final version of the manuscript.

\section{Notes}

The authors declare no competing financial interest.

\section{ACKNOWLEDGMENTS}

The Swedish Research Council (N.K., grant 2015-05360), the Swedish Research Council Formas (N.K., grant 2015-1106), and the Engineering and Physical Sciences Research Council (S.E.L., grant EP/L016354/1) are gratefully acknowledged for funding. We thank Dr. Andrew Paterson, Chemspeed Technologies, for his discussions and Jennifer Tamayo Núñez for her assistance in preparing one of the azulenes.

\section{REFERENCES}

(1) (a) Liu, R. S. H. Colorful azulene and its equally colorful derivatives. J. Chem. Educ. 2002, 79, 183-185. (b) Michl, J.; Thulstrup, E. W. Why is Azulene Blue and Anthracene White Simple MO Picture. Tetrahedron 1976, 32, 205-209. (c) Wheland, G. W.; Mann, D. E. The Dipole Moments of Fulvene and Azulene. J. Chem. Phys. 1949, 17, 264-268.

(2) Ghasimi, S.; Landfester, K.; Zhang, K. A. I. Water Compatible Conjugated Microporous Polyazulene Networks as Visible-Light Photocatalysts in Aqueous Medium. ChemCatChem 2016, 8, 694698.

(3) (a) Murfin, L. C.; López-Alled, C. M.; Sedgwick, A. C.; Wenk, J.; James, T. D.; Lewis, S. E. A simple, azulene-based colorimetric probe for the detection of nitrite in water. Front. Chem. Sci. Eng. 2020, 14, 90-96. (b) Murfin, L. C.; Chiang, K. T.; Williams, G. T.; Lyall, C. L.; Jenkins, A. T. A.; Wenk, J.; James, T. D.; Lewis, S. E. A Colorimetric Chemosensor Based on a Nozoe Azulene That Detects Fluoride in Aqueous/Alcoholic Media. Front. Chem. 2020, 8, No. 10. (c) Xin, H. S.; Li, J.; Yang, X. D.; Gao, X. K. Azulene-Based BN-Heteroaromatics.
J. Org. Chem. 2020, 85, 70-78. (d) Murfin, L. C.; Weber, M.; Park, S. J.; Kim, W. T.; López-Alled, C. M.; McMullin, C. L.; PradauxCaggiano, F.; Lyall, C. L.; Kociok-KohnKociok-Köhn, G.; Wenk, J.; Bull, S. D.; Yoon, J.; Kim, H. M.; James, T. D.; Lewis, S. E. AzuleneDerived Fluorescent Probe for Bioimaging: Detection of Reactive Oxygen and Nitrogen Species by Two-Photon Microscopy. J. Am. Chem. Soc. 2019, 141, 19389-19396. (e) Fang, H.; Gan, Y. T.; Wang, S. R.; Tao, T. A selective and colorimetric chemosensor for fluoride based on dimeric azulene boronate ester. Inorg. Chem. Commun. 2018, 95, 17-21. (f) Lichosyt, D.; Wasiłek, S.; Dydio, P.; Jurczak, J. The Influence of Binding Site Geometry on Anion-Binding Selectivity: A Case Study of Macrocyclic Receptors Built on the Azulene Skeleton. Chem. - Eur. J. 2018, 24, 11683-11692. (g) López-Alled, C. M.; Sanchez-Fernandez, A.; Edler, K. J.; Sedgwick, A. C.; Bull, S. D.; McMullin, C. L.; Kociok-Köhn, G.; James, T. D.; Wenk, J.; Lewis, S. E. Azulene-boronate esters: colorimetric indicators for fluoride in drinking water. Chem. Commun. 2017, 53, 12580-12583. (h) Birzan, L.; Cristea, M.; Drahici, C. C.; Tecuceanu, V.; Hanganu, A.; Ungureanu, E. M.; Razus, A. C. 4-(Azulen-1-y1) six-membered heteroaromatics substituted in 2-and 6-positions with 2-(2-furyl)vinyl, 2-(2-thienyl)vinyl or 2-(3-thienyl) vinyl moieties. Tetrahedron 2017, 73, 2488-2500. (i) Lichosyt, D.; Dydio, P.; Jurczak, J. Azulene-Based Macrocyclic Receptors for Recognition and Sensing of Phosphate Anions. Chem. - Eur. J. 2016, 22, 17673-17680. (j) Wakabayashi, S.; Uchida, M.; Tanaka, R.; Habata, Y.; Shimizu, M. Synthesis of Azulene Derivatives That Have an Azathiacrown Ether Moiety and Their Selective Color Reaction Towards Silver Ions. Asian J. Org. Chem. 2013, 2, 786-791. (k) López-Alled, C. M.; Murfin, L. C.; KociokKöhn, G.; James, T. D.; Wenk, J.; Lewis, S. E. Colorimetric detection of $\mathrm{Hg}^{2+}$ with an azulene-containing chemodosimeter via dithioacetal hydrolysis. Analyst 2020, 6262-6269.

(4) (a) Cowper, P.; Pockett, A.; Kociok-Köhn, G.; Cameron, P. J.; Lewis, S. E. Azulene - Thiophene - Cyanoacrylic acid dyes with donor- $\pi$-acceptor structures. Synthesis, characterisation and evaluation in dye-sensitized solar cells. Tetrahedron 2018, 74, 2775-2786. (b) Xin, H. S.; Ge, C. W.; Jiao, X. C.; Yang, X. D.; Rundel, K.; McNeill, C. R.; Gao, X. K. Incorporation of 2,6-Connected Azulene Units into the Backbone of Conjugated Polymers: Towards HighPerformance Organic Optoelectronic Materials. Angew. Chem., Int. Ed. 2018, 57, 1322-1326. (c) Xin, H. S.; Gao, X. K. Application of Azulene in Constructing Organic Optoelectronic Materials: New Tricks for an Old Dog. ChemPlusChem 2017, 82, 945-956. (d) Nishimura, H.; Ishida, N.; Shimazaki, A.; Wakamiya, A.; Saeki, A.; Scott, L. T.; Murata, Y. Hole-Transporting Materials with a TwoDimensionally Expanded $\pi$-System around an Azulene Core for Efficient Perovskite Solar Cells. J. Am. Chem. Soc. 2015, 137, 1565615659. (e) Puodziukynaite, E.; Wang, H. W.; Lawrence, J.; Wise, A. J.; Russell, T. P.; Barnes, M. D.; Emrick, T. Azulene Methacrylate Polymers: Synthesis, Electronic Properties, and Solar Cell Fabrication. J. Am. Chem. Soc. 2014, 136, 11043-11049.

(5) Hou, I. C. Y.; Berger, F.; Narita, A.; Müllen, K.; Hecht, S. Proton-Gated Ring-Closure of a Negative Photochromic AzuleneBased Diarylethene. Angew. Chem., Int. Ed. 2020, 59, 18532-18536.

(6) Vlasceanu, A.; Koerstz, M.; Skov, A. B.; Mikkelsen, K. V.; Nielsen, M. B. Multistate Photoswitches: Macrocyclic Dihydroazulene/Azobenzene Conjugates. Angew. Chem., Int. Ed. 2018, 57, 60696072.

(7) Zhang, L. Y.; Yang, F.; Shi, W. Q.; Zhang, P.; Li, Y.; Yin, S. F. Synthesis and antigastric ulcer activity of novel 5-isopropyl-3,8dimethylazulene derivatives. Bioorg. Med. Chem. Lett. 2011, 21, 57225725 .

(8) Ikegai, K.; Imamura, M.; Suzuki, T.; Nakanishi, K.; Murakami, T.; Kurosaki, E.; Noda, A.; Kobayashi, Y.; Yokota, M.; Koide, T.; Kosakai, K.; Ohkura, Y.; Takeuchi, M.; Tomiyama, H.; Ohta, M. Synthesis and biological evaluation of $\mathrm{C}$-glucosides with azulene rings as selective SGLT2 inhibitors for the treatment of type 2 diabetes mellitus: Discovery of YM543. Bioorg. Med. Chem. 2013, 21, 39343948. 
(9) Chen, C. H.; Lee, O.; Yao, C. N.; Chuang, M. Y.; Chang, Y. L.; Chang, M. H.; Wen, Y. F.; Yang, W. H.; Ko, C. H.; Chou, N. T.; Lin, M. W.; Lai, C. P.; Sun, C. Y.; Wang, L. M.; Chen, Y. C.; Hseu, T. H.; Chang, C. N.; Hsu, H. C.; Lin, H. C.; Chang, Y. L.; Shih, Y. C.; Chou, S. H.; Hsu, Y. L.; Tseng, H. W.; Liu, C. P.; Tu, C. M.; Hu, T. L.; Tsai, Y. J.; Chen, T. S.; Lin, C. L.; Chiou, S. J.; Liu, C. C.; Hwang, C. S. Novel azulene-based derivatives as potent multi-receptor tyrosine kinase inhibitors. Bioorg. Med. Chem. Lett. 2010, 20, 6129-6132.

(10) (a) Razus, A. C.; Birzan, L. Synthesis of azulenic compounds substituted in the 1-position with heterocycles. Monatsh. Chem. 2019, 150, 139-161. (b) Shoji, T.; Ito, S. Advances in Heterocyclic Chemistry; In Scriven, E. F. V.; Scriven, E. F. V.; Ramsden, C. A., Eds.; Elsevier Science Publishing Co Inc., 2018; Vol. 126, pp 1-54. (c) Ito, S.; Shoji, T.; Morita, N. Recent Advances in the Development of Methods for the Preparation of Functionalized Azulenes for Electrochromic Applications. Synlett 2011, 2279-2298. (d) Kedziorek, M.; Mayer, P.; Mayr, H. Nucleophilic Reactivities of Azulene and Fulvenes. Eur. J. Org. Chem. 2009, 2009, 1202-1206. (e) Anderson, A. G.; Nelson, J. A. Electrophilic Substitution of Azulene. J. Am. Chem. Soc. 1950, 72, 3824-3825.

(11) (a) Devendar, B.; Wu, C. P.; Chen, C. Y.; Chen, H. C.; Chang, C. H.; Ku, C. K.; Tsai, C. Y.; Ku, C. Y. Synthesis, characterization and applications of densely functionalized pyridazines and fulvene-type compounds containing azulene moiety. Tetrahedron 2013, 69, 49534963. (b) Dyker, G.; Muth, E.; Hashmi, A. S. K.; Ding, L. Gold(III) chloride-catalyzed addition reactions of electron-rich arenes to methyl vinyl ketone. Adv. Synth. Catal. 2003, 345, 1247-1252.

(12) Okajima, T.; Kurokawa, S. Facile conversion of 1-methyl group of guaiazulene into 1-formyl group. Chem. Lett. 1997, 69-70.

(13) Shoji, T.; Inoue, Y.; Ito, S. First synthesis of 1-(indol-2yl)azulenes by the Vilsmeier-Haack type arylation with triflic anhydride as an activating reagent. Tetrahedron Lett. 2012, 53, 1493-1496.

(14) Shoji, T.; Ito, S.; Higashi, J.; Morita, N. Synthesis of 1Heteroaryl- and 1,3-Bis(heteroaryl)azulenes: Electrophilic Heteroarylation of Azulenes with the Triflates of N-Containing Heteroarenes. Eur. J. Org. Chem. 2011, 5311-5322.

(15) Tskhovrebov, A. G.; Naested, L. C. E.; Solari, E.; Scopelliti, R.; Severin, K. Synthesis of Azoimidazolium Dyes with Nitrous Oxide. Angew. Chem., Int. Ed. 2015, 54, 1289-1292.

(16) (a) Oda, M.; Thanh, N. C.; Ikai, M.; Fujikawa, H.; Nakajima, K.; Kuroda, S. Synthesis and properties of $N, N, N^{\prime}, N^{\prime}$-tetrasubstituted 1,3-bis(5-aminothien-2-yl)azulenes and their application as a holeinjecting material in organic light-emitting devices. Tetrahedron 2007, 63, 10608-10614. (b) Thanh, N. C.; Ikai, M.; Kajioka, T.; Fujikawa, H.; Taga, Y.; Zhang, Y. M.; Ogawa, S.; Shimada, H.; Miyahara, Y.; Kuroda, S.; Oda, M. Synthesis of $N, N, N^{\prime}, N^{\prime}$-tetrasubstituted 1,3bis(4-aminophenyl)azulenes and their application to a hole-injecting material in organic electroluminescent devices. Tetrahedron 2006, 62, 11227-11239. (c) Muthyala, R. S.; Liu, R. S. H. Synthesis of fluorinated azulenes. J. Fluorine Chem. 1998, 89, 173-175.

(17) (a) Shi, X. Z.; Sasmal, A.; Soule, J. F.; Doucet, H. MetalCatalyzed C-H Bond Activation of 5-Membered Carbocyclic Rings: A Powerful Access to Azulene, Acenaphthylene and Fulvene Derivatives. Chem. Asian J. 2018, 13, 143-157. (b) Carreras, J.; Popowski, Y.; Caballero, A.; Amir, E.; Perez, P. J. Catalytic Functionalization of C-H Bonds of Azulene by Carbene/Nitrene Incorporation. J. Org. Chem. 2018, 83, 11125-11132. (c) Székely, A.; Peter, A.; Aradi, K.; Tolnai, G. L.; Novak, Z. Gold-Catalyzed Direct Alkynylation of Azulenes. Org. Lett. 2017, 19, 954-957. (d) Cowper, P.; Jin, Y.; Turton, M. D.; Kociok-Köhn, G.; Lewis, S. E. Azulenesulfonium Salts: Accessible, Stable, and Versatile Reagents for Cross-Coupling. Angew. Chem., Int. Ed. 2016, 55, 2564-2568. (e) Murai, M.; Yanagawa, M.; Nakamura, M.; Takai, K. Palladium-Catalyzed Direct Arylation of Azulene Based on Regioselective C-H Bond Activation. Asian J. Org. Chem. 2016, 5, 629-635. (f) Park, S.; Yong, W. S.; Kim, S.; Lee, P. H. Diastereoselective $N$-Sulfonylaminoalkenylation of Azulenes from Terminal Alkynes and Azides via N-Sulfonyl-1,2,3-triazoles. Org. Lett. 2014, 16, 4468-4471.
(18) (a) Bromfield, K. M.; Gradén, H.; Ljungdahl, N.; Kann, N. Synthetic applications of cationic iron and cobalt carbonyl complexes. Dalton Trans. 2009, 5051-5061. (b) Pearson, A. J. Iron Compounds in Organic Synthesis; Academic Press Ltd.: London, 1994.

(19) Gree, R. Acyclic butadiene iron tricarbonyl complexes in organic-synthesis. Synthesis 1989, 341-355.

(20) (a) Birch, A. J.; Bandara, B. M. R.; Chamberlain, K.; Chauncy, B.; Dahler, P.; Day, A. I.; Jenkins, I. D.; Kelly, L. F.; Khor, T. C.; Kretschmer, G.; Liepa, A. J.; Narula, A. S.; Raverty, W. D.; Rizzardo, E.; Sell, C.; Stephenson, G. R.; Thompson, D. J.; Williamson, D. H. Organometallic compounds in organic-synthesis. 11. The strategy of lateral control of reactivity - tricarbonylcyclohexadieneiron complexes and their organic synthetic equivalents. Tetrahedron, Supplement 1981, 37, 289-302. (b) Birch, A. J.; Kelly, L. F. Tricarbonyliron methoxycyclohexadiene and dienyl complexes - preparation, properties and applications. J. Organomet. Chem. 1985, 285, 267-280.

(21) Kane-Maguire, L. A. P.; Mansfield, C. A. Cationic Metal-Dienyl Complexes as Electrophilic Reagents on Aromatic Molecules. J. Chem. Soc., Chem. Commun. 1973, 540-541.

(22) Kane-Maguire, L. A. P.; Mansfield, C. A. Kinetics of nucleophilic attack on coordinated organic moieties. Part 4. Mechanisms of addition of indole and substituted indoles to tricarbonyl(cyclohexadienyl)-iron and tricarbonyl(cyclohexadienyl)ruthenium cations. J. Chem. Soc., Dalton Trans. 1976, 2192-2196.

(23) Birch, A. J.; Liepa, A. J.; Stephenson, G. R. Organometallic compounds in organic synthesis. Some tricarbonyl(cyclohexadienyl) iron cations and nitrogen containing nucleophiles. Tetrahedron Lett. 1979, 3565-3568.

(24) Mansfield, C. A.; Al-Kathumi, K. M.; Kane-Maguire, L. A. P. Cationic metal $\pi$-enyl complexes as electrophilic reagents on aromatic molecules. J. Organomet. Chem. 1974, 71, C11-C13.

(25) Dunås, P.; Paterson, A. J.; Kociok-Köhn, G.; Lewis, S. E.; Kann, N. Selective Iron-Mediated $C$ - and O-Addition of Phenolic Nucleophiles to a Cyclohexadiene Scaffold Using Renewable Precursors. ACS Sustainable Chem. Eng. 2019, 7, 7155-7162.

(26) Gordon, M. The Azulenes. Chem. Rev. 1952, 50, 127-200.

(27) (a) Glowacka, P. C.; Maindron, N.; Stephenson, G. R.; Romieu, A.; Renard, P. Y.; Emery, F. D. Synthesis and photophysical properties of iron-carbonyl complex-coumarin conjugates as potential bimodal IR-fluorescent probes. Tetrahedron Lett. 2016, 57, 4991-4996. (b) Anson, C. E.; Creaser, C. S.; Malkov, A. V.; Mojovic, L.; Stephenson, G. R. Flavonoid derivatives as organometallic bioprobes. J. Organomet. Chem. 2003, 668, 101-122. (c) Stephenson, G. R.; Anson, C. E.; Creaser, C. S.; Daul, C. A. Spectroscopic, Structural and DFT Study of the Responses of Carbonylmetal Crown Ether Complexes to Alkali Metal Cations. Eur. J. Inorg. Chem. 2011, 2086-2097.

(28) (a) Ghazvini Zadeh, E. H.; Tang, S.; Woodward, A. W.; Liu, T.; Bondar, M. V.; Belfield, K. D. Chromophoric materials derived from a natural azulene: syntheses, halochromism and one-photon and twophoton microlithography. J. Mater. Chem. C 2015, 3, 8495-8503. (b) Webster, S. J.; López-Alled, C. M.; Liang, X. X.; McMullin, C. L.; Kociok-Köhn, G.; Lyall, C. L.; James, T. D.; Wenk, J.; Cameron, P. J.; Lewis, S. E. Azulenes with aryl substituents bearing pentafluorosulfanyl groups: synthesis, spectroscopic and halochromic properties. New J. Chem. 2019, 43, 992-1000. (c) Tang, T.; Lin, T. T.; Erden, F.; Wang, F.; He, C. B. Configuration-dependent optical properties and acid susceptibility of azulene compounds. J. Mater. Chem. C 2018, 6, 5153-5160. (d) Gai, L. Z.; Chen, J. Z.; Zhao, Y.; Mack, J.; Lu, H.; Shen, Z. Synthesis and properties of azulene-functionalized BODIPYs. RSC Adv. 2016, 6, 32124-32129. (e) Murai, M.; Takami, K.; Takeshima, H.; Takai, K. Iridium-Catalyzed Dehydrogenative Silylation of Azulenes Based on Regioselective C-H Bond Activation. Org. Lett. 2015, 17, 1798-1801. (f) Murai, M.; Ku, S. Y.; Treat, N. D.; Robb, M. J.; Chabinyc, M. L.; Hawker, C. J. Modulating structure and properties in organic chromophores: influence of azulene as a building block. Chem. Sci. 2014, 5, 3753-3760. (g) Koch, M.; Blacque, O.; Venkatesan, K. Impact of 2,6-connectivity in azulene: 
optical properties and stimuli responsive behavior. J. Mater. Chem. C 2013, 1, 7400-7408.

(29) (a) Shoji, T.; Sugiyama, S.; Kobayashi, Y.; Yamazaki, A.; Ariga, Y.; Katoh, R.; Wakui, H.; Yasunami, M.; Ito, S. Direct synthesis of 2arylazulenes by $[8+2]$ cycloaddition of $2 \mathrm{H}$-cyclohepta[b]furan-2-ones with silyl enol ethers. Chem. Commun. 2020, 56, 1485-1488. (b) Ohtsu, K.; Hayami, R.; Sagawa, T.; Tsukada, S.; Yamamoto, K.; Gunji, T. Syntheses and properties of linear $\pi$-conjugated molecules composed of 1-azaazulene and azulene. Tetrahedron 2019, 75, No. 130658. (c) Gao, H. L.; Yang, X. D.; Xin, H. S.; Gao, T. Z.; Gong, H. G.; Gao, X. K. Design, Synthesis and Properties of 2/6-Aryl Substituted Azulene Derivatives. Chin. J. Org. Chem. 2018, 38, 26802692. (d) Amir, E.; Murai, M.; Amir, R. J.; Cowart, J. S.; Chabinyc, M. L.; Hawker, C. J. Conjugated oligomers incorporating azulene building blocks - seven- vs. five-membered ring connectivity. Chem. Sci. 2014, 5, 4483-4489. (e) Koch, M.; Blacque, O.; Venkatesan, K. Syntheses and Tunable Emission Properties of 2-Alkynyl Azulenes. Org. Lett. 2012, 14, 1580-1583. (f) Amir, E.; Amir, R. J.; Campos, L. M.; Hawker, C. J. Stimuli-Responsive Azulene-Based Conjugated Oligomers with Polyaniline-like Properties. J. Am. Chem. Soc. 2011, 133, 10046-10049.

(30) Grellmann, K. H.; Heilbronner, E.; Seiler, P.; Weller, A. Proton dissociation of azulenium cations in excited state. J. Am. Chem. Soc. 1968, 90, 4238-4242.

(31) (a) Jaouen, G.; Vessieres, A.; Top, S.; Ismail, A. A.; Butler, I. S. Metal-carbonyl fragments as a new class of markers in molecularbiology. J. Am. Chem. Soc. 1985, 107, 4778-4780. (b) Lam, Z. Y.; Kong, K. V.; Olivo, M.; Leong, W. K. Vibrational spectroscopy of metal carbonyls for bio-imaging and -sensing. Analyst 2016, 141, $1569-1586$.

(32) Franck-Neumann, M.; Heitz, M. P.; Martina, D. A simple method of freeing organic-ligands from their iron carbonyl-complexes. Tetrahedron Lett. 1983, 24, 1615-1616.

(33) Holmes, J. D.; Pettit, R. Synthesis and Properties of Homotropone. J. Am. Chem. Soc. 1963, 85, 2531-2532.

(34) Shvo, Y.; Hazum, E. Simple Method for Disengagement of Organic Ligands from Iron Complexes. J. Chem. Soc., Chem. Commun. 1974, 336-337.

(35) Thompson, D. J. Reaction of tricarbonylcyclohexadieneiron complexes with cupric chloride. J. Organomet. Chem. 1976, 108, 381383.

(36) Knölker, H. J.; Goesmann, H.; Klauss, R. Transition metal complexes in organic synthesis, part 48. A novel method for the demetalation of tricarbonyliron-diene complexes by a photolytically induced ligand exchange reaction with acetonitrile. Angew. Chem., Int. Ed. 1999, 38, 702-705.

(37) Bergh, A.; Gradén, H.; Pera, N. P.; Olsson, T.; Nilsson, U. J.; Kann, N. Carbohydrate functionalization using cationic iron carbonyl complexes. Carbohydr. Res. 2008, 343, 1808-1813.

(38) (a) Krahl, M. P.; Kataeva, O.; Schmidt, A. W.; Knölker, H. J. Iron-Mediated Total Synthesis of 2,7-Dioxygenated Carbazole Alkaloids. Eur. J. Org. Chem. 2013, 2013, 59-64. (b) Pearson, A. J.; Kole, S. L.; Yoon, J. Stereocontrolled Double Functionalization of (Cyclohexadiene)-Iron and (Cycloheptadiene)Iron Complexes Via Oxidative Cyclization Techniques. Organometallics 1986, 5, 20752081.

(39) Song, J. F.; Hansen, H. J. An improved and simplified synthesis of 4-styrylazulenes. Helv. Chim. Acta 1999, 82, 309-314.

(40) Kurokawa, S. Reaction of 3-(2-substituted ethenyl)guaiazulenes with alkenes. Nippon Kagaku Kaishi 1997, 365-372.

(41) (a) Gong, J.; Sun, P.; Jiang, N.; Riccio, R.; Lauro, G.; Bifulco, G.; Li, T. J.; Gerwick, W. H.; Zhang, W. New Steroids with a Rearranged Skeleton as (h)P300 Inhibitors from the Sponge Theonella swinhoei. Org. Lett. 2014, 16, 2224-2227. (b) Li, J.; Tang, H.; Kurtan, T.; Mandi, A.; Zhuang, C. L.; Su, L.; Zheng, G. L.; Zhang, W. Swinhoeisterols from the South China Sea Sponge Theonella swinhoei. J. Nat. Prod. 2018, 81, 1645-1650.

(42) Duecker, F. L.; Heinze, R. C.; Heretsch, P. Synthesis of Swinhoeisterol A, Dankasterone A and B, and Periconiastone A by
Radical Framework Reconstruction. J. Am. Chem. Soc. 2020, 142, 104-108.

(43) Leivers, M.; Tam, I.; Groves, K.; Leung, D.; Xie, Y. L.; Breslow, R. A forbidden rearrangement. Org. Lett. 2003, 5, 3407-3409.

(44) Birch, A. J.; Chamberlain, K. Tricarbonyl[(2,3,4,5- $\eta)-2,4-$ cyclohexadien-1-one $]$ iron and tricarbonyl $[(1,2,3,4,5-\eta)-2$-methoxy2,4-cyclohexadien-1-yl]iron(1+) hexafluorophosphate(1-) from anisole. Org. Synth. 1977, 57, No. 107.

(45) Treibs, W.; Neupert, H. J.; Hiebsch, J. Uber bicyclische und polycyclische Azulene. 37. Synthesen und Eigenschaften von Azulenaldehyden. Chem. Ber. 1959, 92, 141-154.

(46) Lash, T. D.; El-Beck, J. A.; Ferrence, G. M. Syntheses and reactivity of meso-unsubstituted azuliporphyrins derived from 6-tertbutyl- and 6-phenylazulene. J. Org. Chem. 2007, 72, 8402-8415.

(47) Narita, M.; Murafuji, T.; Yamashita, S.; Fujinaga, M.; Hiyama, K.; Oka, Y.; Tani, F.; Kamijo, S.; Ishiguro, K. Synthesis of 2Iodoazulenes by the Iododeboronation of Azulen-2-ylboronic Acid Pinacol Esters with Copper(I) Iodide. J. Org. Chem. 2018, 83, 12981303.

(48) Ito, S.; Terazono, T.; Kubo, T.; Okujima, T.; Morita, N.; Murafuji, T.; Sugihara, Y.; Fujimori, K.; Kawakami, J.; Tajiri, A. Efficient preparation of 2-azulenylboronate and Miyaura-Suzuki crosscoupling reaction with aryl bromides for easy access to poly(2azulenyl)benzenes. Tetrahedron 2004, 60, 5357-5366.

(49) Crombie, A. L.; Kane, J. L.; Shea, K. M.; Danheiser, R. L. Ring expansion-annulation strategy for the synthesis of substituted azulenes and oligoazulenes. 2. Synthesis of azulenyl halides, sulfonates, and azulenylmetal compounds and their application in transition-metalmediated coupling reactions. J. Org. Chem. 2004, 69, 8652-8667.

(50) Ho, T. I.; Ku, C. K.; Liu, R. S. H. Preparation of 1-arylazulenes through regioselective photoarylation of azulene with aryl iodides. Tetrahedron Lett. 2001, 42, 715-717. 